\title{
Is the Strawberry Tree, Arbutus unedo (Ericaceae), native to Ireland, or was it brought by the first copper miners?
}

\author{
Micheline Sheehy Skeffington ${ }^{1 *}$ and Nick Scott ${ }^{2}$ \\ ${ }^{1}$ Botany \& Plant Science, NUI Galway, Ireland ${ }^{2}$ Clarinbridge, Co. Galway, Ireland
}

*Corresponding author: Micheline Sheehy Skeffington:

micheline.sheehy@nuigalway.ie

This pdf constitutes the Version of Record published on 30 $30^{\text {th }}$ December 2021

\begin{abstract}
The Strawberry Tree (Arbutus unedo L.) is often referred to as one of Ireland's 'Lusitanian' species to describe its disjunct distribution, since it is absent from Britain and is mainly found around the Mediterranean Sea and on the Iberian Peninsula. In Ireland, it is regarded as native in the south-west and in Co. Sligo. However, a recent genetic study suggests that it could have been introduced to Ireland directly from northern Spain. This possibility was previously dismissed, since palynological and archaeological evidence showed it to be present in south-west Ireland 4,000 years ago. Here, we examine how an introduction might have occurred prior to this date, by first reviewing what is known of its distribution, ecology and history in Ireland along with archaeological information. Then, combining an updated distribution of $A$. unedo where it is regarded as native in Ireland with historical accounts, palynological and archaeological records and other information from the literature, we present two online maps, designed to be an ongoing accessible resource. The information has enabled us to propose a means by which $A$. unedo might have arrived in Ireland with miners who came to work the first known copper mine in north-west Europe, in the Chalcolithic phase of the Late Neolithic, which was at Ross Island on Lough Leane in Co. Kerry. The species' distribution today suggests that it then spread with subsequent Bronze Age copper mining activity in south-west Ireland, though this is unlikely to account for its arrival in Co. Sligo. Previous suggestions that $A$. unedo was once much more widely distributed in Ireland and subsequently contracted due to preferential cutting for smelting, are shown to be unfounded.
\end{abstract}

Key words: Bronze Age; Chalcolithic; copper mining; disjunct distribution; genetics; Lusitanian species.

\section{Introduction}

The Strawberry Tree (Arbutus unedo L.) occupies a special place in Irish traditional and botanical lore as it is an attractive, rare and unusual small tree, which has been noted by many botanists since Parkinson (1640) mentioned it as in the 'West part of Ireland'. It is today considered native in counties Kerry (v.C.H1 \& H2; Fig. 1), West 
Cork (v.c.H3) and Sligo (v.c.H28), although it is often claimed that it was once more widespread (Tansley, 1949; Proctor, 2002).

Arbutus unedo is one of a group of Irish 'Lusitanian' species with distinctly disjunct distributions: they occur only in the western regions of Ireland, not at all in Britain and for most, their nearest, or principal, localities are on the Iberian Peninsula (Praeger, 1934; Webb, 1983). For over 150 years there has been debate as to how these species came to be in Ireland; in particular how they could have reinvaded Ireland naturally after the last ice age (e.g. Forbes, 1846; Scully, 1916; Praeger, 1932b; Webb, 1983). But these species have little in common, with very different distributions and habitat preferences. Some are montane, others heathland species and $A$. unedo is principally a Mediterranean tree. $A$. unedo thus seems particularly unlikely to have survived an ice age either in Ireland, or in a sincesubmerged refuge nearby, as proposed for other 'Lusitanian' species such as Daboecia cantabrica (Beatty \& Provan, 2013). Indeed, Godwin (1975) singled it out as 'impossible' to have survived what would have been at best a periglacial climate in Ireland and surrounding regions, also noting no earlier inter-glacial fossil record.

Although the native status of $A$. unedo in Ireland has occasionally been questioned, palynological and archaeological finds have since established that the species was present in Ireland c.4,000 years ago (Vokes, 1966; Mitchell and Watts, 1970; Van Rijn, 2004). This led to the firm conclusion that the species must therefore be native (Mitchell, 1993; Mitchell and Cooney, 2004), which has not so far been questioned.

However, recently, Santiso et al. (2016) investigated the genetics of $A$. unedo populations across its entire range and concluded inter alia that the population sampled from Ireland must be a relatively recent introduction because of the absence of any private haplotypes unique to Ireland and, as it was genetically similar to populations in Iberia and not France, that the most likely origin for the Irish population was Iberia, something already suggested by Kelleher (2013) following a preliminary genetic investigation.

So, if this is the case, how might that introduction have occurred, and could it have been aided by humans? In this paper we consider this possibility by initially reviewing what is known to date about $A$. unedo in Ireland. We then describe and map its updated distribution, along with historical, placename, archaeological and palynological records. Its potential arrival and subsequent spread in Ireland are discussed in the light of these results.

\section{Review of Arbutus unedo in, and in relation to, Ireland Distribution \\ Arbutus unedo is in effect a Mediterranean species (Webb, 1972; Tison \& de} Foucault, 2014), sometimes called Hiberno-Mediterranean (Praeger, 1932b; Sealy \& Webb, 1950). Its native distribution is very disjunct with the inclusion of Ireland (Fig. 2). It has become naturalised in other parts of Ireland and in Britain (Hackney, 1998; Green, 2007; Proctor, 2002) and, north of the Loire estuary in France, it is now mostly regarded as naturalised (des Abbayes et al., 1971; Tison \& de Foucault, 2014; Fig. 2). 


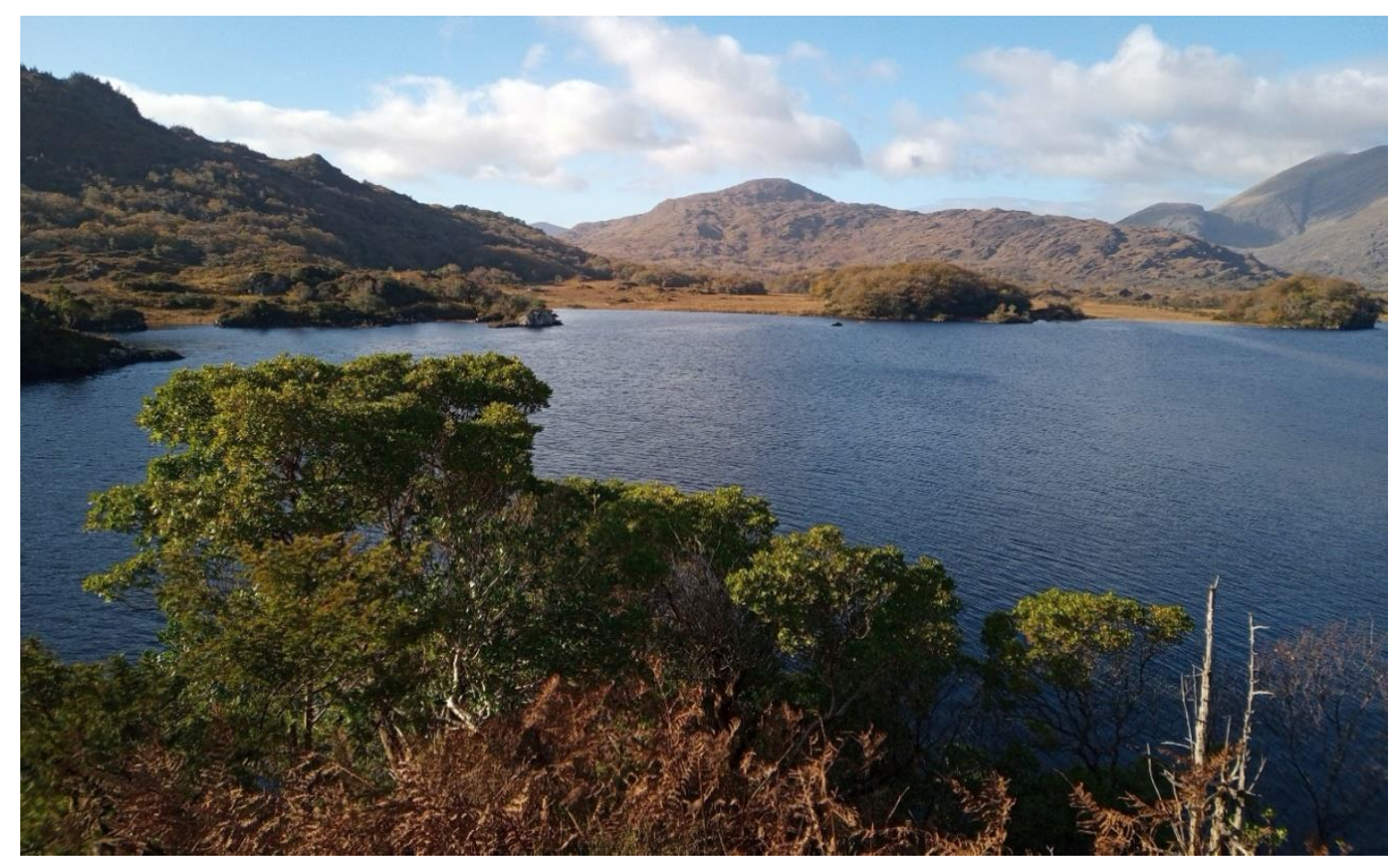

Figure 1. Arbutus unedo growing in a typical habitat in Co Kerry; on the top of a cliff overhanging water, in this case Upper Lake, Killarney. Image: Rory Hodd

Its absence inland in the Balkans, Turkey and North Africa suggests it avoids more arid climates, whereas northwards and eastwards it seems intolerant of colder continental climates (Blanco et al., 1997); in Iberia it is notably widespread in the (sub)oceanic (Atlantic) regions (Torres et al., 2002; Fig. 2).

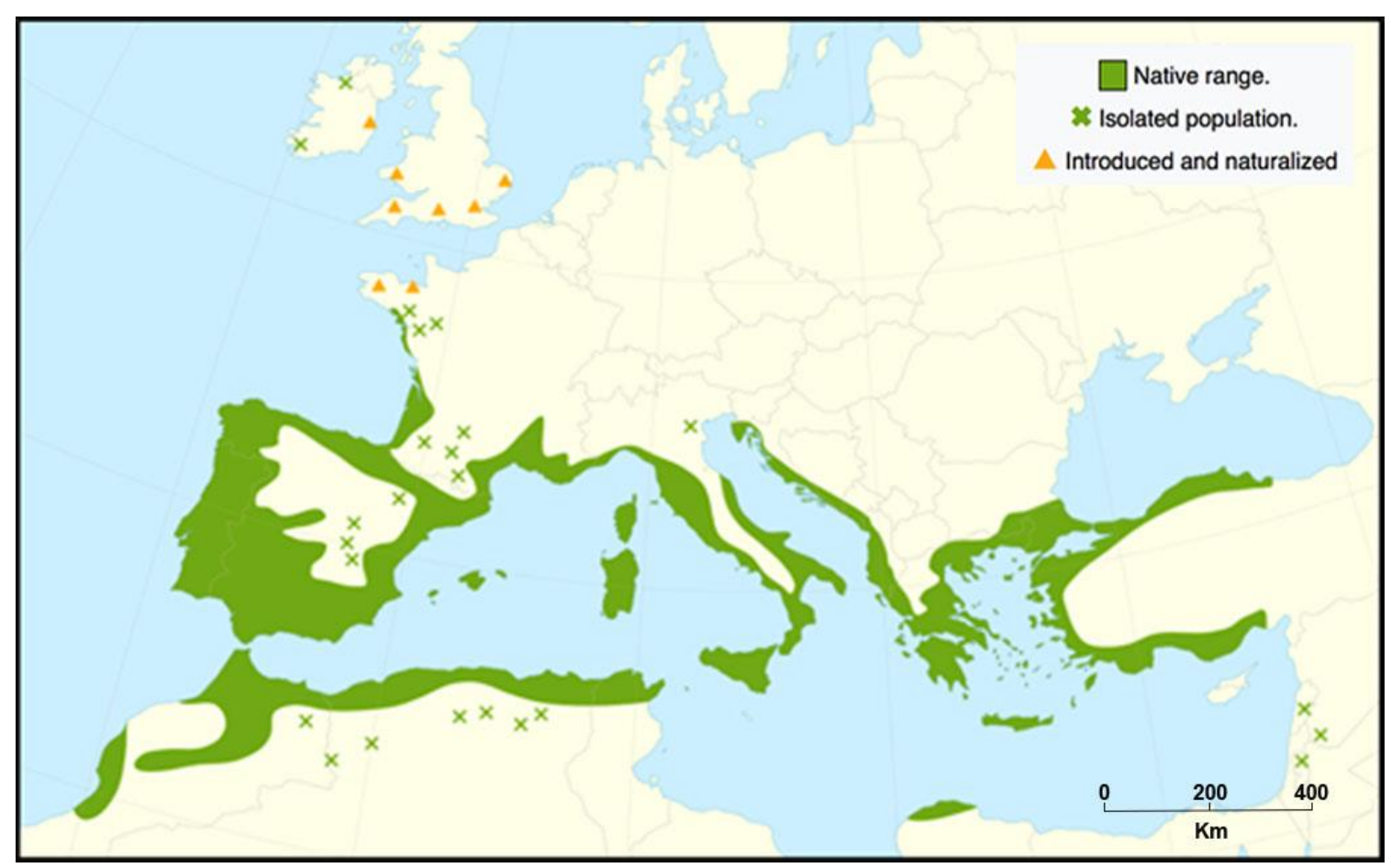

Figure 2. Distribution of Arbutus unedo in Europe and N. Africa. From Caudullo et al. (2017). 
Within Ireland it also has a disjunct distribution; in south-west Ireland it occurs primarily around the Lakes of Killarney, Co Kerry, and sporadically on the nearby Beara and Mizen Peninsulas in West Cork, and then much further north, as a small population around Lough Gill in Co. Sligo (Praeger, 1932a; Preston et al., 2002; Fig. 3). Praeger (1934) searched for it in vain on lakes with similar habitat between Sligo and Kerry. Because of documented declines in occurrence especially over recent decades, it is listed as 'Near Threatened' in the Irish Red List for vascular plants (Wyse Jackson et al., 2016).

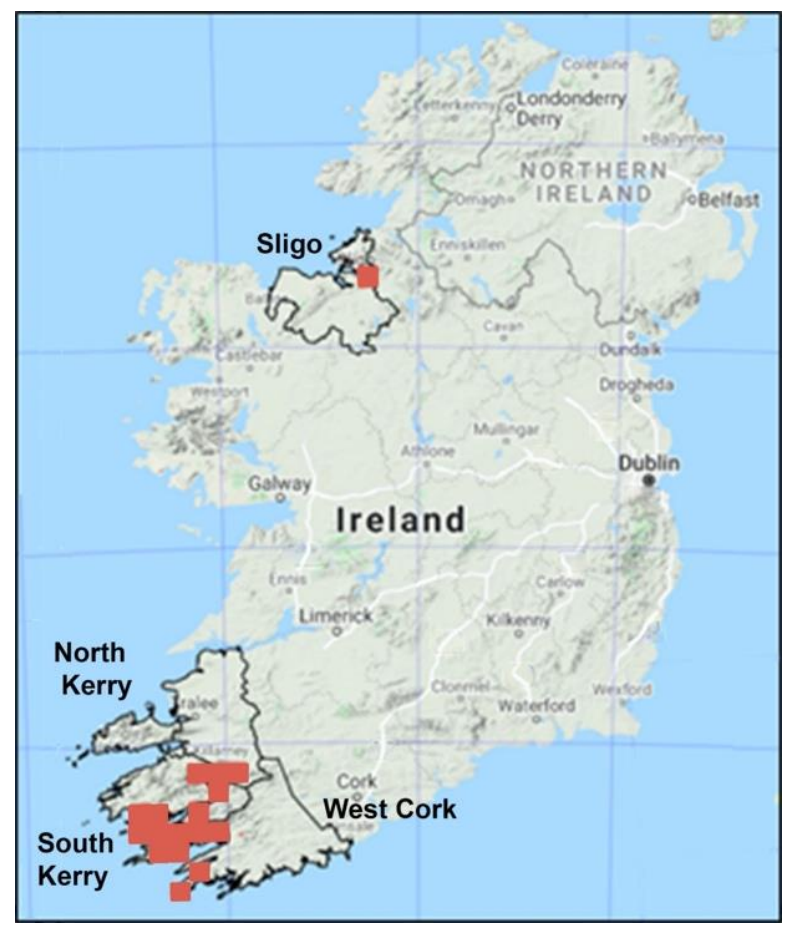

Figure 3. Distribution of Arbutus unedo in vice counties where it is considered native in Ireland, mapped at hectad $\left(\mathbf{1 0} \mathrm{km}^{2}\right)$ level (BSBI Distribution Database; accessed 24.3.2021).

Debate on the origins of Arbutus unedo in Ireland

Perhaps because of its exotic appearance, $A$. unedo has occasionally been considered a 'doubtful native' (see Power, 1845). However, botanists mostly assume it to be native and have focused on the mechanisms whereby it and other 'HibernoLusitanian' species might have come to Ireland. Forbes (1846) had an elaborate scenario of 'great geological operations' that linked northern Spain to Ireland in the Miocene, implying that these species survived the glacial periods in situ. Later, Scully (1916) and Praeger (1934) still held the view that $A$. unedo was among those that survived glaciation. However, it is now accepted that the ice advanced over Ireland (Mitchell \& Ryan, 1998; Clark et al., 2012), perhaps even well south of Ireland (Praeg et al., 2015), to an extent that the climate would have been periglacial at best, precluding the survival of cold-sensitive species in particular.

An alternative theory is that $A$. unedo followed a similar pattern to most other plant species that migrated (back) to Ireland from a refugium further south (e.g. Birks, 1989; Hewitt, 1999; Mitchell, 2006). Sealy (1949) suggested that $A$. unedo migrated northwards via western France to southern England and Ireland, with 
subsequent extinction in the intervening regions. Webb (1983) had no explanation other than the suitably vague 'long range dispersal'. Since it is thought that $A$. unedo is limited by a minimum mean January temperature of $4.5^{\circ} \mathrm{C}$ both latitudinally and altitudinally (Sealy \& Webb, 1950), it is unlikely to have been amongst the pioneer woody species recolonising post-glacial Ireland, but could have arrived 7,000 or at least 6,000 years ago. However, the new phylogenetic evidence means an alternative scenario must be considered.

\section{Phylogeography}

The recent study of $A$. unedo (Santiso et al., 2016) provides information on its genetic composition and variability across Europe. Sequencing four chloroplast fragments isolated from $A$. unedo leaves sampled from 23 populations across its entire distribution, the authors identified two key lineages, one centred on SW Iberia and the other on the Mediterranean coasts of France and Italy, with other populations exhibiting variants derived from these. The authors suggest that these represent populations that survived in two geographically-disjunct refugia during the last glaciation, one in south Iberia/Morocco, the other in the region of Sardinia (Fig. 4).

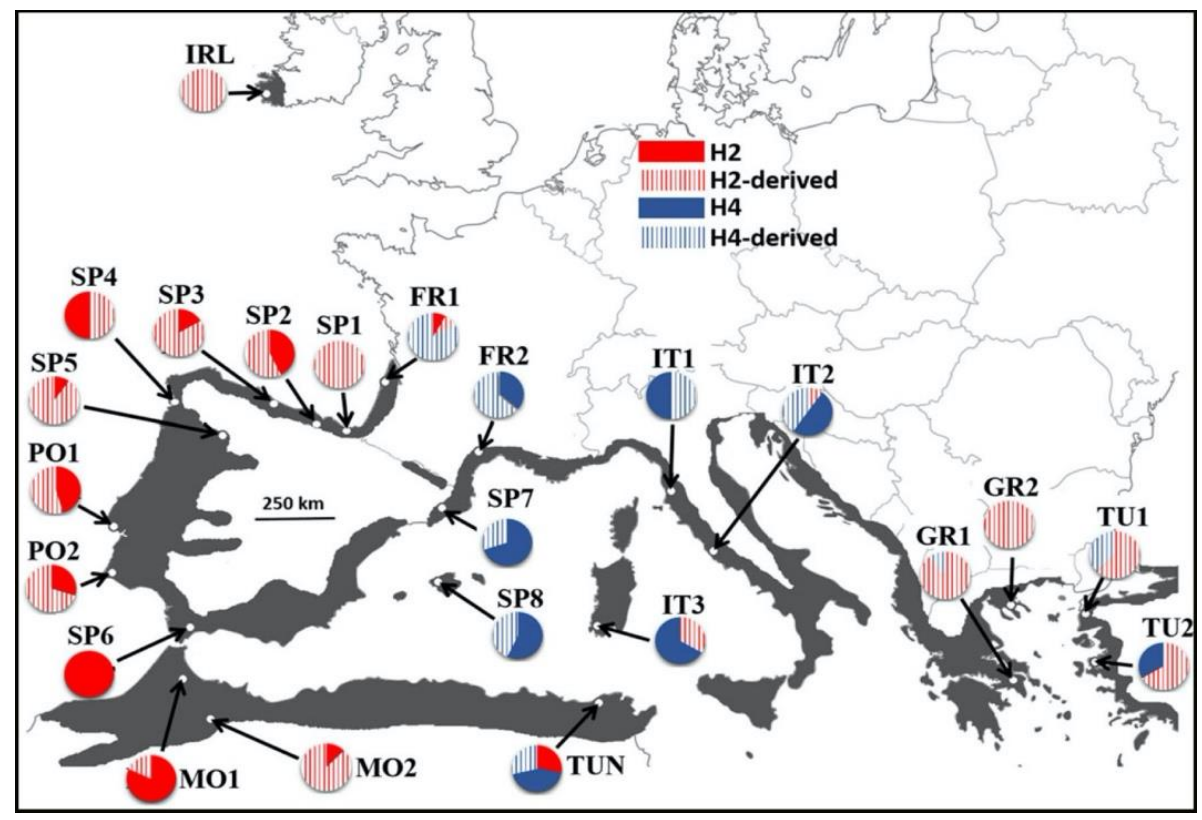

Figure 4. Map of population frequencies of $\mathrm{cp}$ DNA lineages across the distribution range of Arbutus unedo (shaded). The two main haplotypes are $\mathrm{H} 2$ and H4. From Santiso et al. (2016).

Significantly, the Irish $A$. unedo population sampled (around Killarney) showed no unique genetic haplotypes and seemed closest genetically to the populations sampled from northern Iberia, specifically to that sampled near San Sebastián and is thus of Iberian lineage; it was also shown to be genetically quite different from the population sampled near Bordeaux in France, which clearly connects to the Italy/southern France lineage, separated by the Pyrenees (Santiso et al., 2016; Fig. 4). Those authors conclude that the Irish population sampled must both be a recent 
introduction and one which could not have come via the population sampled in south-west France.

\section{Ecology}

In southern Europe, $A$. unedo is a species of shrubby sclerophyllous open-canopied communities on rocky terrain called maquis on acid and garrigue on limestone rocks (Bonfils, 1990; Veuillen, 2016). Both habitats are prone to drought, and frequent fire leads in France to a shrubby, somewhat 'degraded' community of Quercus ilex, $A$. unedo and Cistus spp. (Bonfils, 1990; Hétier, 1994). A key $A$. unedo adaptation is its ability to re-sprout from a lignotuber at its base, so that most individuals become multi-stemmed after disturbance (Sealy, 1949; Mesléard \& Lepart, 1989).

In Ireland, $A$. unedo is found mostly on lake shores, islands and peninsulas, or woodland margins on exposed crags or cliffs (Praeger, 1932a; Praeger, 1934; Webb, 1948; Tansley, 1949; Sealy \& Webb, 1950). It occurs predominantly on shallow welldrained soils on both sandstone and limestone (Scully, 1916; Sealy, 1949; Sealy \& Webb,1950). Its intolerance of waterlogging (Sealy, 1949) explains its absence from the widespread wet blanket bogs of south-west Ireland.

As a pioneer woody species in Ireland, it invades suitable habitat, persisting amidst heathland or scrub, but excluded when this becomes woodland (Tansley, 1949; Kelly, 1981). Associated heathland species include heather Calluna vulgaris and western gorse Ulex gallii; in woodland, sessile oak Quercus petraea, holly Ilex aquifolium and rowan Sorbus aucuparia are common and on limestone, yew Taxus baccata is a frequent companion with rock whitebeam Sorbus rupicola (Praeger, 1932a; Sealy, 1949; Sealy \& Webb, 1950; Kelly, 1981; Cotton \& Sheehy Skeffington, 2021).

Arbutus unedo is extremely light requiring (Sealy, 1949; Sealy \& Webb, 1950) and Webb (1948) noted that in woodland it was 'tall, thin and struggling with a meagre crown of foliage projecting well above the canopy', concluding that such individuals were 'probably doomed' and that the trees must have become established before the woodland re-developed (Fig. 5). Around Lough Gill in Sligo, most $A$. unedo trees are now struggling under taller, denser trees, particularly yew and beech and exposed rock faces act as refuges from shade and grazing (Cotton \& Sheehy Skeffington, 2021).

Attempting to explain why it was so often confined to lake margins in Ireland, Praeger (1932a) ascertained that no seed, fruit, or fruit attached to branches, could float. $A$. unedo fruit is eaten by a wide variety of birds (Sealy \& Webb,1950), which are probably the primary means of dispersal to new rocky habitat (Blanco et al., 1997).

The moderately maritime distribution of $A$. unedo reaches its extreme in the hyperoceanic west of Ireland, where it is at the northern edge of its ecological range. It survives most winters, but stems can be killed by exceptional frosts, then regrowing from the base. It is thought not to survive in a climate at or below a mean January temperature of $38^{\circ} \mathrm{F}\left(3.3^{\circ} \mathrm{C}\right)$ (Sealy, 1949). The maximum altitude for an $A$. unedo record in Ireland was $500 \mathrm{ft}(152 \mathrm{~m})$ on the southern slopes of Macgillycuddy's Reeks, Co. Kerry (Scully, 1916), though Sealy is said to have traced it to $750 \mathrm{ft}(228 \mathrm{~m})$ in rocky gullies on Cromaglan Mountain nearby (Webb, 1948). However, recently O'Malley (2001) reported it at c.230 m on a cliff in the Gap of Dunloe in the Reeks. In Sligo, it is only found at sea level, beside Lough Gill 
(Praeger, 1932a), and never on apparently suitable adjacent mountain crags, probably due to the colder climate that far north (Cotton \& Sheehy Skeffington, 2021).

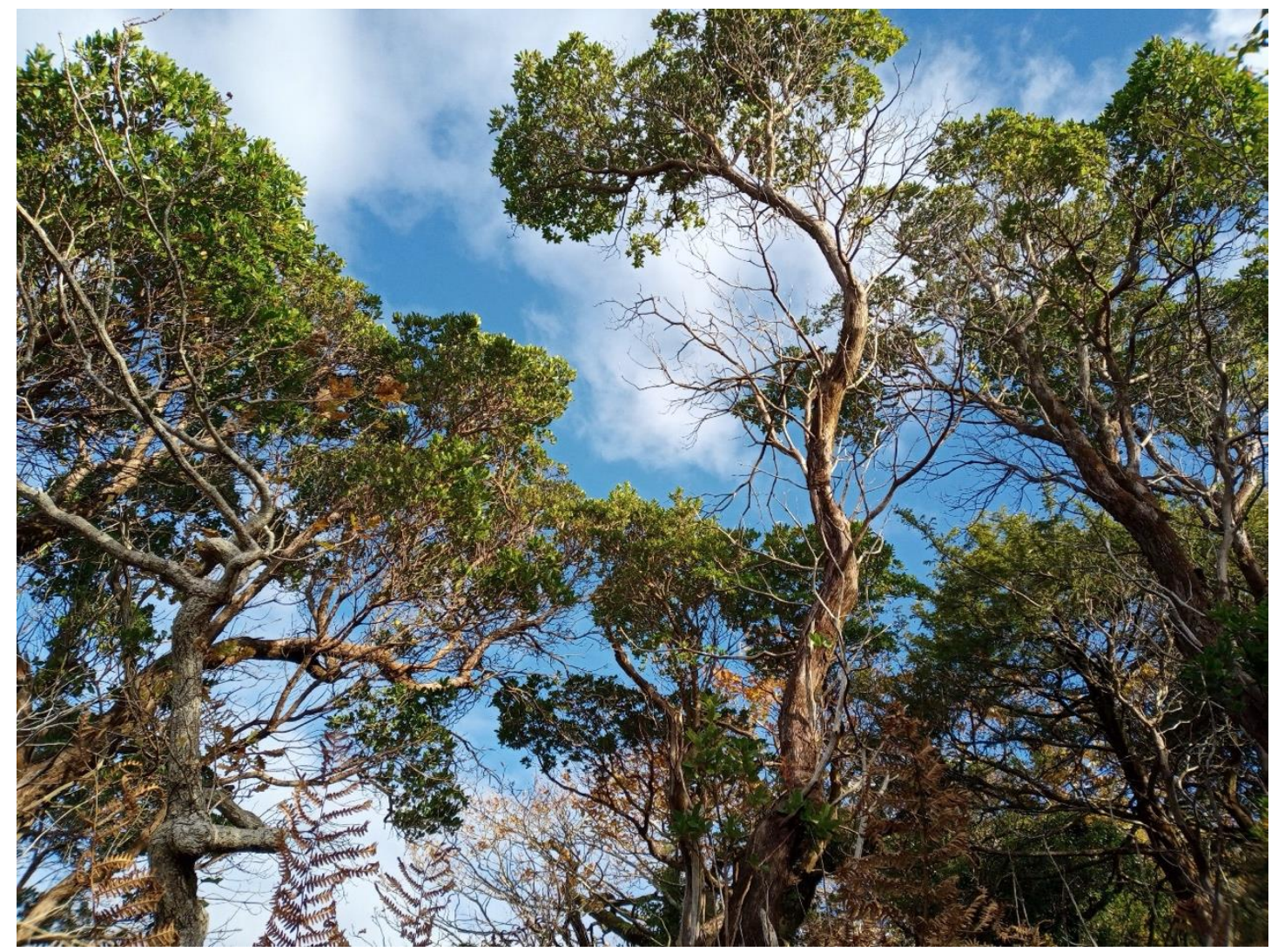

Figure 5. Arbutus unedo growing as a single stemmed tree amongst others on Ronayne's Island, Upper Lake, Killarney. This form of the tree is a temporary phenomenon, lasting until the trees are overtopped by larger species. Image: Rory Hodd

Growth ring counts of several trunks in Kerry, where one of girth $57 \mathrm{~cm}$ was 142 years old, showed $A$. unedo to be slow growing, and the largest trunk found was estimated to be at least 500-600 years old (Webb, 1948). However, Webb reckoned that as the trunks continually regenerate from the base, $A$. unedo could, in fact, be 'almost immortal'. Praeger (1932a) also described the largest trees around Lough Gill in Sligo as having 'sprouted again and again ... indicating a very great age'.

\section{Historical accounts}

Arbutus unedo is listed as one of the 'lower divisions of the wood' in the early $8^{\text {th }}$ century Irish Brehon laws (Kelly, 1976), the cutting down of which would incur a fine of a 2-year-old calf (Kelly, 1999). But the first actual record of the species is in the 1584 survey of Rory O'Donoghue's property, which noted $A$. unedo growing on the islands of Lough Leane near Killarney (M'Enery, 1906). Parkinson (1640) says it 'hath been of late days found in the West part of Ireland' where the trees were growing 'of their own accord'. Ray (1696) refers to 'Kerry (where the Arbutus grows)' and Threlkeld (1726) mentions Glengarriff, Co. Cork as well as the 'Borders of Loghlen' 
(Lough Leane). Bishop Dive Downes, in his account of a tour of West Cork in 16991700 , makes much of $A$. unedo at Hungry Hill on the south of the Beara Peninsula where, 'in a small wood at the bottom of the hill' he saw 'a hundred of arbutus trees' and near Crookhaven at the tip of the Mizen Peninsula, 'some' were growing 'out of the clefts of the rocks' (Brady, 1863; Anon., 2003). The first mention for Co. Sligo, by Wakefield (1812), is much later.

\section{Placenames}

One reason why $A$. unedo is thought to be native in Ireland is its occurrence in placenames said to derive from its Irish name caithne, many of which are outside its current range. Joyce (1875) lists several, suggesting that places like Quin in Co. Clare got their name from cuinche, as a form of caithne. Scully (1916) quotes this, adding the name of an island in Clew Bay, Co. Mayo (Quinsheen) and proposes that $A$. unedo must have once been much more widespread in Ireland. This is still repeated today, and Hall (2011) adds names such as Feaghquin in Co. Clare and Cappoquin in Co. Waterford. However modern Irish linguists do not support most of these proposals (see Irish placename data base www.logainm.ie). Kelly (1999) also dismisses the possibility that cuinche is a form of caithne, but he does suggest that Derrynacaheny Wood in Co. Clare (Westropp, 1908) is derived from the Irish Doire na Caithne, oakwood of the Arbutus.

Appendix 1 lists all published proposals for Irish placenames that refer to $A$. unedo, along with assessments of their veracity by Irish experts. Only three outside the present distribution for $A$. unedo are accepted by Kelly $(1976,1999)$ and/or Logainm.ie as likely to have been derived from caithne: Smerwick Harbour (Ard na Caithne) in the Dingle Peninsula, Co. Kerry; Ardcanny (Ard Caithne) on the Shannon estuary in Co. Limerick and Derrynacaheny Wood in Co. Clare. An indication that $A$. unedo must never have been that widespread in Ireland, is that three versions of the $8^{\text {th }}$ century Irish tree list substitute honeysuckle Lonicera periclymenum for $A$. unedo (Kelly, 1999).

\section{Accounts of changes in $A$. unedo abundance}

In some places $A$. unedo seems to have been much more abundant a few centuries ago. Only a handful of scattered trees remain on Hungry Hill, Co. Cork (Scannell \& O'Donnell, 1994; Garvey \& Flynn, 1995; Clare Heardman, pers. comm.), where Bishop Downes found 100 trees 'in a small wood' in 1700 (Anon., 2003). Significantly, the wood is no longer present.

Scully (1916) makes frequent reference to scattered often senescent trees around Kerry, noting $A$. unedo to be much rarer than when Smith (1756) stated that 'it covered at least a fourth part of the ascent of the mountains' around Lough Leane where 'upwards of 40 Islands in this lake are covered with an intermixture of these trees'. Scully also notes the remarks of Molyneux (1697) on the $A$. unedo size, reaching $41 / 2$ feet $(1.4 \mathrm{~m})$ in circumference and ' 9 or 10 yards' $(8-9 \mathrm{~m})$ high and his statement that $A$. unedo was 'in such plenty that they now cut them down as the chief Fewel to melt and refine the Ore of the silver and lead mine ... near the Castle of Rosse'. This account suggests that $A$. unedo was targeted for smelting, as its charcoal was valued (Nelson \& Walsh, 1993; Wyse Jackson, 2014). That the cutting was responsible for its local decline became added to the belief, based on placenames, that $A$. unedo was once more widespread, not just more abundant. 
Even Tansley (1949) says that 'formerly the Irish distribution was much more extensive, but its widespread use as firewood has severely restricted its occurrence'. This is repeated in the Atlas of the British and Irish Flora (Proctor, 2002).

In Sligo it has declined, at least in the last century. Since Praeger's survey (1932a), only about half remain of the $c .60$ trees he recorded (Cotton and Sheehy Skeffington, 2021).

\section{Myths}

One tenuous but intriguing reference to $A$. unedo, as ubhla caithne, occurs in the tale of the pursuit of Diarmaid and Gráinne. As part of the Fiannaíocht or Fenian cycle of legends, the story recounts how Oisín and the Fianna arrive at Glenflesk (the River Flesk flows into Lough Leane) and, encountering the Tuatha Dé Danann already ensconced around the lake, the Fianna abandon plans for a game of 'goal' and 'decided to go back'. The next description of the people they met is surprisingly detailed: "Agus as é lón tugadar leo as Tír threabhar-ghlain Tharrngaire .i. cnó corcra agus ubhla caithne agus caora cumhra". "And the provisions they brought with them from fair-cultivated Tír Thairngire were crimson nuts and arbutus berries and sweet berries ..." (Ní Shéaghdha, 1967).

This edition of the story is based on several $17^{\text {th }}-18^{\text {th }}$ century manuscripts, in turn based on older $10^{\text {th }}$ century accounts (Ní Shéaghdha, 1967), so the script is only evidence of knowledge dating back at best to early Christian times. However, the legends are well-documented and overlap with other tales of mythical peoples and lands.

It is intriguing that $A$. unedo is specifically mentioned, since it may not have been widely known in Ireland in medieval times (Kelly, 1976, 1999). The produce is also said to have been brought by newcomers from a foreign land. An alternative translation to Tír threabhar-ghlain is 'land of industrious agriculture', which could be an interpretation of southern climates where tillage and fruit-growing would have been more common than in Ireland. Roman writers refer to Ireland, in contrast, as being rich in a grassy sward, such that grazing cattle quickly reach satiety (O'Donovan, 1860). The fact that $A$. unedo is specifically mentioned associated with people who had settled around Lough Leane may just be a mythologising of the attractive tree associated with that lake, but it might not. Nelson and Walsh (1993) dismiss any veracity to this legend, but it resonates intriguingly with the evidence described below.

\section{Palynological and Archaeological Evidence for A. unedo in Ireland}

The oldest pollen record for $A$. unedo (one grain from that depth) is from a core in a bog above Upper Lough Leane, Killarney (Vokes, 1966) later estimated by comparison with other local peat cores to date to 'perhaps as early as' 4,000 years ago (Mitchell \& Watts, 1970; FJG Mitchell, pers. comm.). This has been corroborated by the discovery of $A$. unedo charcoal associated with the mining on Ross Island, Lough Leane, dating to $c .4,200$ years ago (Van Rijn, 2004).

Even when a pollen core is taken very close to $A$. unedo, its pollen can be missed, as it is produced in low quantity and is large, so does not travel far (Vokes, 1966; Mitchell, 1993). Yet $A$. unedo pollen was found to have an almost continuous 
small presence from c.2280 $\pm 70 \mathrm{BP}^{1}$ about $1 \mathrm{~km}$ from Vokes' site, in a small basin at Derrycunihy Wood above Upper Lough Leane, while at Camillan Wood, on the Muckross Peninsula on L. Leane, it was rare, found only in the pollen zone dated between $3720 \pm 80 \mathrm{BP}$ and $1095 \pm 50 \mathrm{BP}$ (Mitchell, 1988). A. unedo is frequent at both sites today.

On the Beara Peninsula, about $30 \mathrm{~km}$ south of Lough Leane, $A$. unedo was found to be almost continuously present since at least $c .2000 \mathrm{BP}$ in a mor humus profile from an island on Lough Inchiquin (Fig. 6; Mitchell, 1993). It is present from the start of the profile, when charcoal indicates extensive burning. Mitchell attributes the continuous presence of $A$. unedo to the ideal marginal rocky habitat of the small island. It would also be relatively free from grazing.

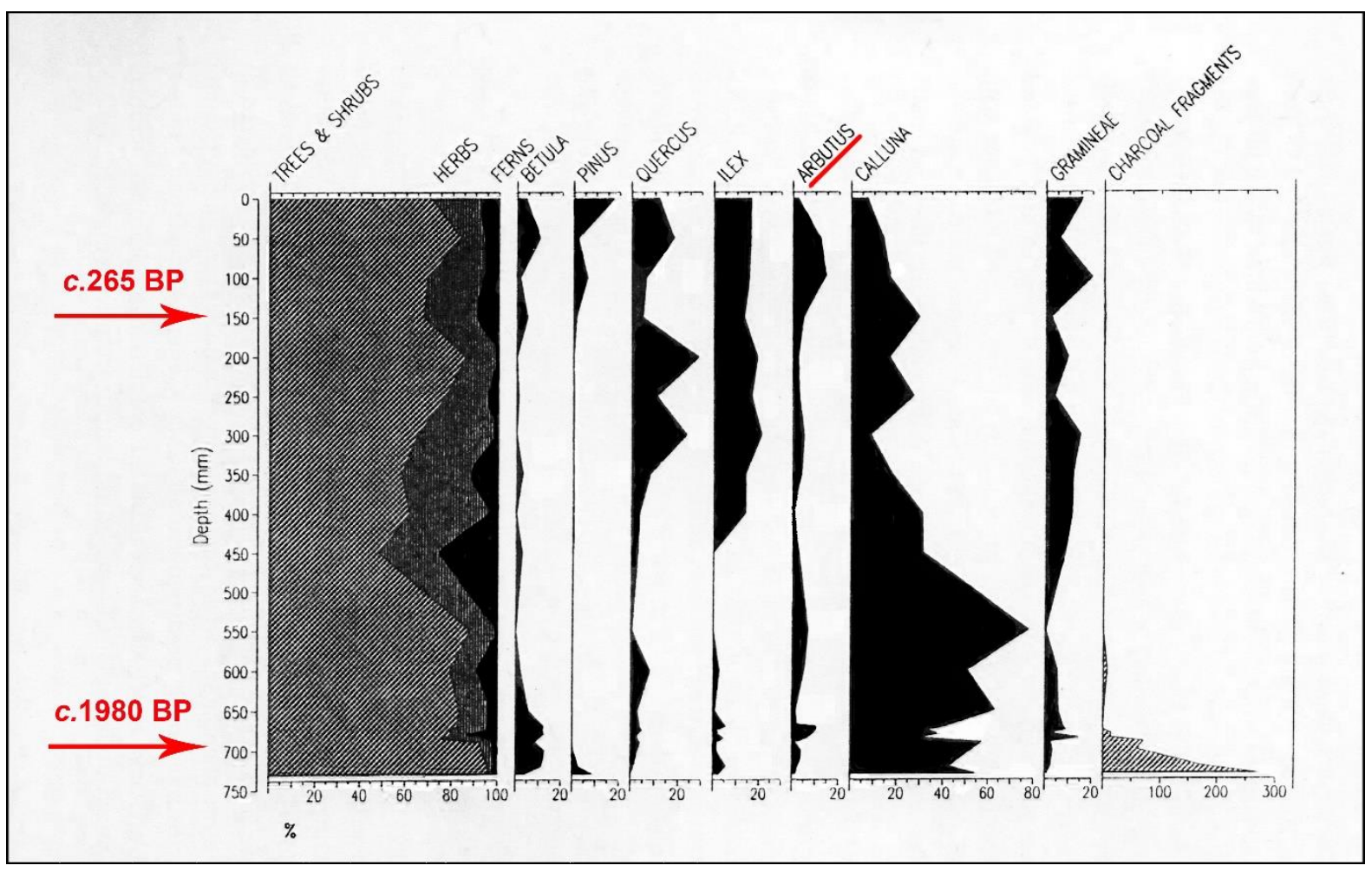

Figure 6. Percentage pollen diagram for selected taxa from an island on Lough Inchiquin, Co. Kerry. From Mitchell (1993) with approximate dates for pine horizons from a core taken c.1 km away (Little et al., 1996; FJG Mitchell pers. comm.). Reproduced with permission of the Irish Biogeographical Society.

At Camillan Wood and on nearby Rough Island, $19-25 \mathrm{~cm}$ mor humus monoliths chronicle woodland recovery after more recent fire events about 500 years ago, followed by the highest percentage of $A$. unedo pollen (9.6\%) recorded for any site at Killarney (Mitchell, 1990).

The only place outside these sites where $A$. unedo pollen has been recorded is in Co. Sligo, where a small amount was determined (confirmed by FJG Mitchell) in two cores taken from Slish Lake, beside Lough Gill a kilometre east of the nearest

\footnotetext{
${ }^{1} \mathrm{BP}=$ number of years before 1950 . We use BP for all radiocarbon dates not calibrated for radiocarbon fluctuation. All dates calibrated in the source reference are expressed as $B C$ or $A D$. We only calibrate a date ourselves if a calibration graph is provided in a publication for that specific site, which we then cite.
} 
site for $A$. unedo today; the oldest estimated at $c .1900 \mathrm{BP}$ from an adjacent radiocarbon date (Dodson \& Bradshaw, 1987). This $A$. unedo pollen, found at the base of each core, showed a peak corresponding with an increase in charcoal levels, a decrease in tree species and the expansion of heathland species (Dodson \& Bradshaw, 1987).

As part of an extensive multidisciplinary archaeological study of the Bronze Age copper mining site at Ross Island, Lough Leane, Co. Kerry (O'Brien, 2004), Van Rijn (2004) examined various charcoal remains. Mesolithic charcoal assemblages dating to before the start of mining comprising oak $(>80 \%)$, alder and ash, suggest that the site was then largely covered by mature oak woodland. $A$. unedo remnants were only found in Early Bronze Age charcoal assemblages associated with the mining and smelting activity, and not until $2200-1800 \mathrm{BC}$ (calibrated using Lanting, 2004), some 200 years after the mining activity started, when $A$. unedo comprised $c .3 \%$ of charcoal found (Van Rijn, 2004). The decrease in oak and increase in $A$. unedo and other light-loving species in this charcoal was interpreted as indicating a change locally from oak woodland to open scrub. One exact date for $A$. unedo is given, by association with a radiocarbon dated bone, of $3730 \pm 50 \mathrm{BP}$ which calibrates to 2150 $\pm 50 \mathrm{BC}$ (using Lanting, 2004). The $A$. unedo charcoal was only associated with 'silt' and 'work camp spoil', which derive from a range of activities, so no conclusions could be drawn regarding its specific uses (Van Rijn, 2004).

\section{Early Copper Mining in Ireland}

Extensive archaeological work on Ross Island established that copper mining began there $c .2400 \mathrm{BC}$, in the Chalcolithic age, prior to the Bronze Age, when copper was used, not bronze, and that it continued to $c .1900 \mathrm{BC}\left(\mathrm{O}^{\prime} \mathrm{Brien}, 2004\right)$. This is the earliest copper mining known in north-west Europe eventually providing copper for Britain and Ireland during the Chalcolithic and Early Bronze Ages (O'Brien, 2004; Timberlake, 2014). The Welsh monk Nennius, writing around 1,200 years ago, probably had this location in mind when he listed the mineral wealth of Lough Leane as one of the wonders of the world (O'Brien, 2004).

Archaeologists generally believe that copper mining and smelting technology is a marker for radical change and was brought to northern Europe with the Beaker culture (O'Brien, 2015). This may have been part of a cultural and linguistic movement along the Atlantic fringe, originating from southern Iberia (Cunliffe \& Koch, 2010). First broached by Quinn $(1984,2018)$, focus is now on the development of a proto-Celtic culture on the Atlantic margin of Europe, which then moved east, rather than coming from the east, as previously proposed (Cunliffe, 2010). The nearest copper mining and smelting known to have occurred before that at Ross Island, is in northern Iberia (O'Brien, 2015).

In the Early to Middle Bronze Age, as the available copper at Ross Island dwindled, copper mining started at other sites to the south and west of Lough Leane, using the same fire setting and stone hammer techniques as at Ross Island. However, these mines were in much lower grade seams with less available copper, so each was worked only for decades rather than 500 years as at Ross Island and probably by local communities for their own use (O'Brien, 2012). The largest known congregation of these mines is at Mount Gabriel on the Mizen Peninsula Co. Cork, worked from $1800 \mathrm{BC}$ to $1400 \mathrm{BC}$ (O'Brien, 2015), but older ones have been found 
on the Mizen Peninsula and others occur on the adjacent peninsulas. All that have been dated are from the Early to Middle Bronze Age (O'Brien, 2015).

\section{Present study: Map compilation and field work}

To define the current distribution of $A$. unedo in Ireland we used the Botanical Society of Britain and Ireland (BSBI) Distribution Database (https://database.bsbi.org/) and worked with the BSBI Vice-county Recorders (VCRs) for the four vice-counties where $A$. unedo is regarded as native, who gave us an understanding of the principal sites and helped us survey other sites, sometimes finding new records. We also undertook a thorough literature search for any reliable record of $A$. unedo in Ireland prior to 1950.

\section{South-west Ireland}

All post-1950 BSBI database records for $A$. unedo that were specific at least to monad level $\left(1 \mathrm{~km}^{2}\right)$ were plotted online using a Google custom 'my map'. Grid references no more precise than monad level, were plotted at the most likely point within that monad, as guided by the VCR. Details of the recorder, comments on quantity, habitat and whether planted, are in a pop-up box specific to each record.

A second layer includes all pre-1950 records from BSBI and the literature. Those with sufficient information were mapped at approximately the right place, but older records citing just a general locality were placed in the centre of that named area. The information box gives details including the source.

A third layer gives placenames derived from the Irish for $A$. unedo (see Appendix 1), or English names (outside urban situations) that include either Arbutus or Strawberry Tree. The information box includes the source for the interpretation. The fourth layer has Palaeobotanical $A$. unedo records with precise locations of pollen cores and archaeological macrofossil remains with estimated dates and source in the information box.

The Google custom map also includes the position of known Bronze Age copper mines, which in Ireland only occur in this region, mostly based on records from the Archaeological Survey of Ireland online Historic Environment Viewer (https://maps.archaeology.ie/HistoricEnvironment/). Details of each mine are provided in its information box. We have added a few further published ancient copper mining records, giving the source for each. A separate layer of records was created for modern copper mines and other possible copper workings using the Mindat online database (https://www.mindat.org/).

The resulting map is available on-line and will continue to be updated as a resource by both ourselves and VCRs, who can be sent new records. Each layer can be switched on/off and different backgrounds chosen, including a satellite view. It can be viewed here:

https://www.google.com/maps/d/u/0/edit?mid=1Zb216s6p3xsYsgZEZjDHxVo591Z0e ZMR\&usp=sharing

\section{Sligo}

All the sites located around Lough Gill by Praeger (1932a) and Cotton \& Sheehy Skeffington (2021) were plotted on another Google custom map, including information on number of individuals and habitat. Mention of $A$. unedo in earlier literature was not specific enough to enable mapping. The sites for pollen cores in 
which $A$. unedo pollen was recorded (Dodson \& Bradshaw, 1987) are also marked, as is the only possible ancient mine. The link is here:

https://www.google.com/maps/d/u/0/edit?mid=1lS8xCId6dhGbJJuIqdB5JcWZtPpoIP $\underline{m} 5 \& \|=54.23661523517244 \% 2 \mathrm{C}-8.446818049999996 \& \mathrm{z}=12$

\section{Present study: Results}

Arbutus unedo records in SW Ireland

Fig. 7 shows a screenshot of the online map. Seven distinct clusters of $A$. unedo records are evident, detailed in Table 1 . The clusters are numbered by the amount of $A$. unedo trees they include, from several thousand in Cluster 1: Lough Leane and surrounds, to just five for Cluster 7: Ardgroom. Each cluster includes old records, often very old, and/or placenames in Irish, or pollen records, indicating $A$. unedo is not an introduction of recent centuries. None of the clusters includes estates that could have planted $A$. unedo in the past, except Cluster 1, where the records predate estate planting.

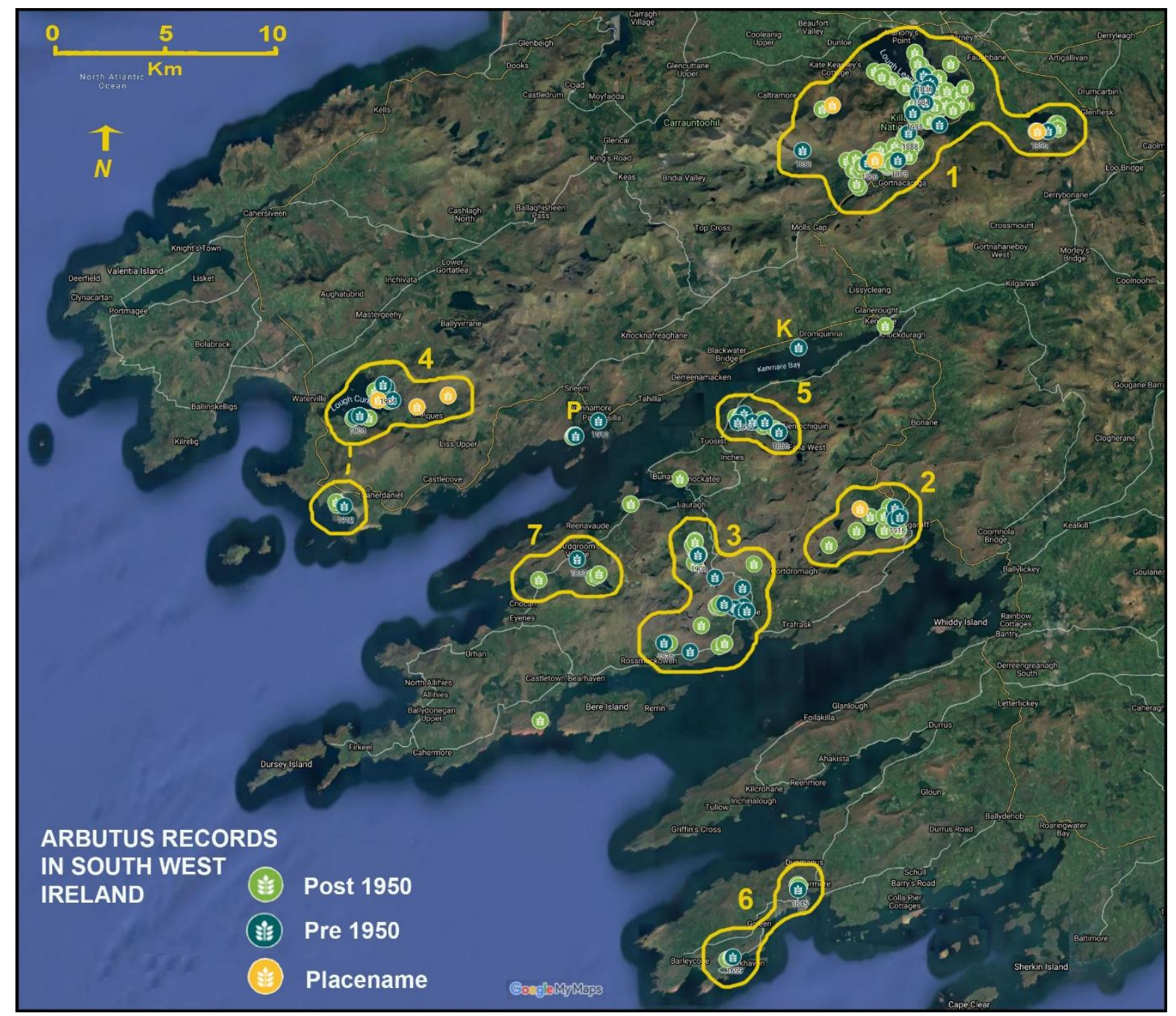

Figure 7. Screenshot of online map showing all records for Arbutus unedo in south-west Ireland with clusters outlined. Table 1 has information on clusters. ' $P$ ' Parknasilla, 'K' Islands in Kenmare Bay. 
All current $A$. unedo records not clearly part of these clusters have a possible means of recent introduction. The only ones not for a single tree are for Garinish Island, and nearby Parknasilla on the Iveragh Peninsula, Co. Kerry (indicated by ' $P$ ' in Fig. 7). Both were once part of the Derryquin Estate and Scully (1916) suggests that $A$. unedo may have been planted there. The estate was established in 1732 by Rev. Dr Nathaniel Bland, Vicar of Killarney (Stoakley, 1986), then living near Lough Leane with its $A$. unedo trees. He or his son, who inherited the estate and the Killarney benefice, may well have planted $A$. unedo within Derryquin. The records for isolated individuals are from beside a road, near an obvious source (a garden centre) or situated to suggest planting, such as beside a bench on a coastal path. In addition, there is an old record by Smith (1756) for several islands 'towards the head of Kenmare River', where Scully (1916) reports $A$. unedo as 'not seen ... recently and probably long since destroyed for smelting purposes'. The most likely site for this is indicated by 'K' on Fig. 7. However, Smith was not a botanist, so the record could be a mistake.

Table 1. Clusters of Arbutus unedo records in south-west Ireland (Fig. 7). See details in online map

\begin{tabular}{|c|c|c|c|}
\hline $\begin{array}{l}\text { Cluster } \\
\text { no. }\end{array}$ & $\begin{array}{l}\text { Site name \& } \\
\text { (Vice } \\
\text { County) }\end{array}$ & Details of $A$. unedo & $\begin{array}{l}\text { Date of first } \\
\text { record }\end{array}$ \\
\hline 1 & $\begin{array}{l}\text { Lough Leane } \\
\text { and } \\
\text { surrounds } \\
(\mathrm{H1}, \mathrm{H2})\end{array}$ & $\begin{array}{l}\text { Common on islands and around shores of } \\
\text { Lough Leane, Muckross Lake and the Upper } \\
\text { Lake; between and above these, rising up } \\
\text { lower mountainsides as occasional } \\
\text { individuals on crags or cliffs. On bluffs at } \\
\text { Lough Guitane } c .4 \mathrm{~km} \text { to E. Placenames } \\
\text { with caithne. Several pollen records. }\end{array}$ & $\begin{array}{l}2150 \pm 50 \mathrm{BC} \\
\text { Charcoal } \\
\text { (Van Rijn, } \\
\text { 2004) }\end{array}$ \\
\hline 2 & $\begin{array}{l}\text { Glengarriff } \\
\text { (H3) }\end{array}$ & $\begin{array}{l}\text { Over } 200 \text { trees, most within Glengarriff } \\
\text { Woods, on crags and cliffs; further E on } \\
\text { mountain cliffs. One placename with } \\
\text { caithne. No pollen cores. }\end{array}$ & $\begin{array}{l}1726 \mathrm{AD} \\
\text { (Threlkeld, } \\
1726)\end{array}$ \\
\hline 3 & $\begin{array}{l}\text { Hungry } \\
\text { Hill/Adrigole } \\
(\mathrm{H} 3 \& \mathrm{H} 2)\end{array}$ & $\begin{array}{l}\text { A few trees, widely spread, including on } \\
\text { Glanmore Lake, on northern side of Healy } \\
\text { Pass (Henry, 1908). Oldest record: Hungry } \\
\text { Hill. }\end{array}$ & $\begin{array}{l}1700 \text { AD } \\
\text { (Downes in } \\
\text { Anon., 2003) }\end{array}$ \\
\hline 4 & $\begin{array}{l}\text { Lough } \\
\text { Currane } \\
\text { (H2) }\end{array}$ & $\begin{array}{l}\text { Scattered trees on S shore, on islets and at } \\
\text { remote SE end of lake; mountain slopes } \\
\text { and gullies above. Three placenames with } \\
\text { caithne. } \\
\text { Population at Derrynane, on S side of } \\
\text { mountain ridge includes dead trunk } 1.57 \mathrm{~m} \\
\text { girth (= c.300 yrs) by low sea cliffs, } 1 \mathrm{~km} \mathrm{~W} \\
\text { of Derrynane House, may be part of this } \\
\text { cluster. Scully (1916) thought Derrynane } \\
\text { trees possibly planted, but no } A \text {. unedo in } \\
\text { garden. Trees E of Caherdaniel; } 1976 \mathrm{~J} \text {. } \\
\text { O'Shea pers. comm. \& this survey. }\end{array}$ & $\begin{array}{l}1890 \text { AD } \\
\text { (Scully, 1916) }\end{array}$ \\
\hline
\end{tabular}




\begin{tabular}{|l|l|l|l|}
\hline $\mathbf{5}$ & $\begin{array}{l}\text { Cloonee } \\
\text { Loughs \& } \\
\text { Inchiquin } \\
\text { (H2) }\end{array}$ & $\begin{array}{l}\text { Trees on crags mostly on islets in Cloonee } \\
\text { Loughs Middle \& Upper and Lough } \\
\text { Inchiquin. }\end{array}$ & $\begin{array}{l}\text { c.2000 BP } \\
\text { Pollen } \\
\text { (Mitchell, } \\
1993) .\end{array}$ \\
\hline $\mathbf{6}$ & $\begin{array}{l}\text { Crookhaven } \\
\mathbf{( H 3 )}\end{array}$ & $\begin{array}{l}\text { At Crookhaven; two multiple crown clusters } \\
\text { on high inaccessible cliff ledges; each } \\
\text { possibly just one old tree. Single tree at } \\
\text { Ballyrisode 7 km to E. }\end{array}$ & $\begin{array}{l}\text { 1699 AD } \\
\text { Downes in } \\
\text { Brady (1863) }\end{array}$ \\
\hline $\mathbf{7}$ & $\begin{array}{l}\text { Ardgroom } \\
\mathbf{( H 3 )}\end{array}$ & $\begin{array}{l}\text { Three records; one recent for old group of } \\
\text { trees on remote lowland cliff 1 km from 2 } \\
\text { cores taken at Barrees (Overland \& } \\
\text { O'Connell, 2008), which found no A. unedo } \\
\text { pollen. }\end{array}$ & $\begin{array}{l}\text { 1883 AD } \\
\text { near Ardgroom' } \\
\text { (T. Allin in } \\
\text { Moore \& More; } \\
1898)\end{array}$ \\
\hline
\end{tabular}

Bronze Age Mining and A. unedo in south-west Ireland

There is a correlation between the seven clusters of $A$. unedo and the distribution of Bronze Age copper mines. Each has an ancient mine site within the same valley (see online map), except Cluster 5, which has a nearby quarry with an exposed copper seam (online map), indicating the area does have available copper. However, the converse is not so clear; many sites with Bronze Age copper mines have no $A$. unedo records, particularly around Mount Gabriel.

Only Cluster 1: Lough Leane has a Bronze Age copper mine well within the distribution of $A$. unedo, at Ross Island (O'Brien, 2004). With the other clusters, the nearby mining site is on a mountainside above the valley containing most of the $A$. unedo records, e.g. Cluster 3: Hungry Hill/Adrigole has two Bronze Age copper mines nearby (Fig. 8).

There is no correlation between $A$. unedo records and the distribution of wedge tombs, which it is suggested may have been built and used by the same peoples who brought copper smelting and Beaker pottery to Ireland (O'Brien, 2012).

\section{Sligo - A. unedo distribution}

In Co. Sligo, all known $A$. unedo records occur on the western half of Lough Gill, on rocky headlands or woodland edges (Cotton \& Sheehy Skeffington, 2021). The distribution has contracted since Praeger's (1932a) survey, which in turn does not encompass the pollen records (Fig. 9).

\section{Ecology}

Field work and information from local recorders provided updates on the current status and ecology of $A$. unedo in Ireland.

In Kerry and West Cork, most trees seen were healthy and growing robustly. Nearly all were on cliffs or crags, many beside or just above a lake, where $A$. unedo limbs leaned straight out towards the light, away from taller trees above. In the woods around the Killarney Lakes and at Glengarriff, some $A$. unedo trees were on crags surrounded and overtopped by larger tree species and often, unusually, singlestemmed and apparently struggling, with leaves only at the very top. Where there was grazing, $A$. unedo was confined to inaccessible sites. If goats or sheep could still reach these, $A$. unedo had been preferentially grazed over other trees, with leaves, shoots, and bark missing from the available side of the tree. 


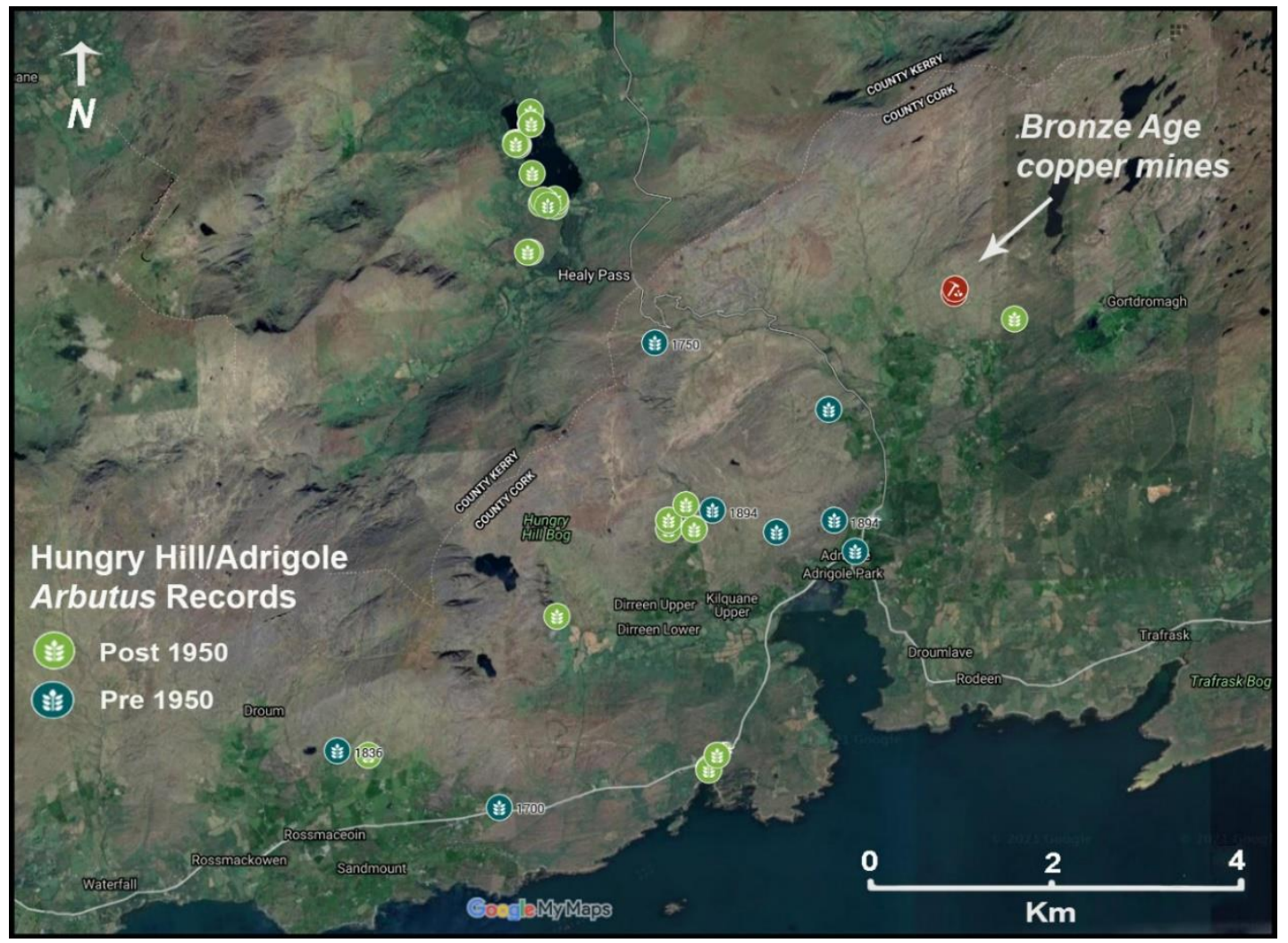

Figure 8. Google map screenshot of Cluster 3: Hungry Hill/Adrigole with records for Arbutus unedo and two Bronze Age copper mines. The pre-1950 records are not exact locations.

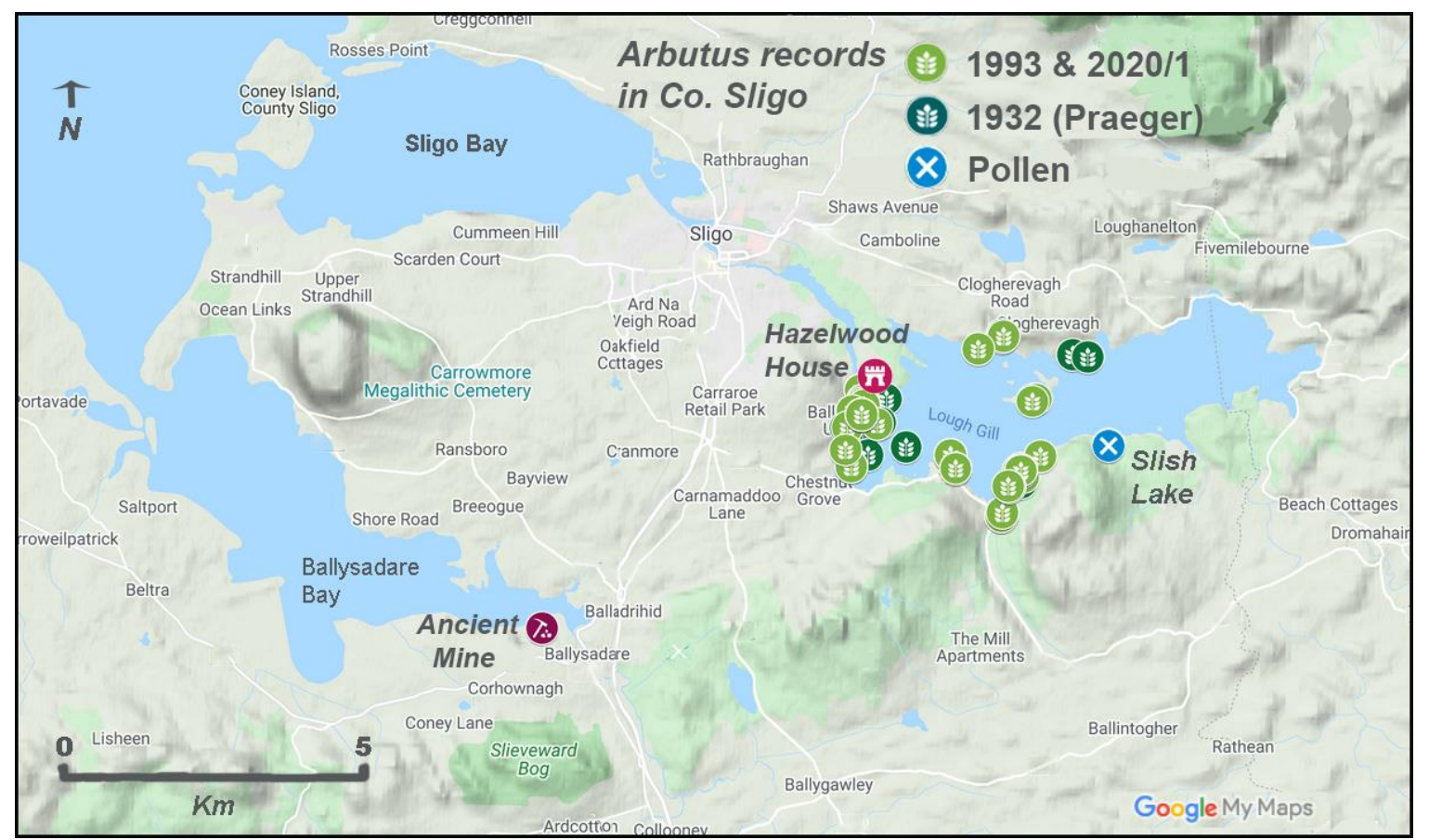

Figure 9. Google map screenshot of Arbutus unedo records in Co. Sligo, with sites from Praeger (1932a) marked, as well as individual trees (Cotton \& Sheehy Skeffington, 2021), palynological records, Hazelwood House and the only known possible ancient mine (see Discussion). 
Many apparently very old individuals had several trunks, some dead, emerging vertically from a wide lignotuber or a now-collapsed decaying trunk. It was often difficult to tell whether these were several individuals growing near each other or simply one which had sprouted several separate trunks. Most trees had new shoots appearing at their base (Fig. 10).

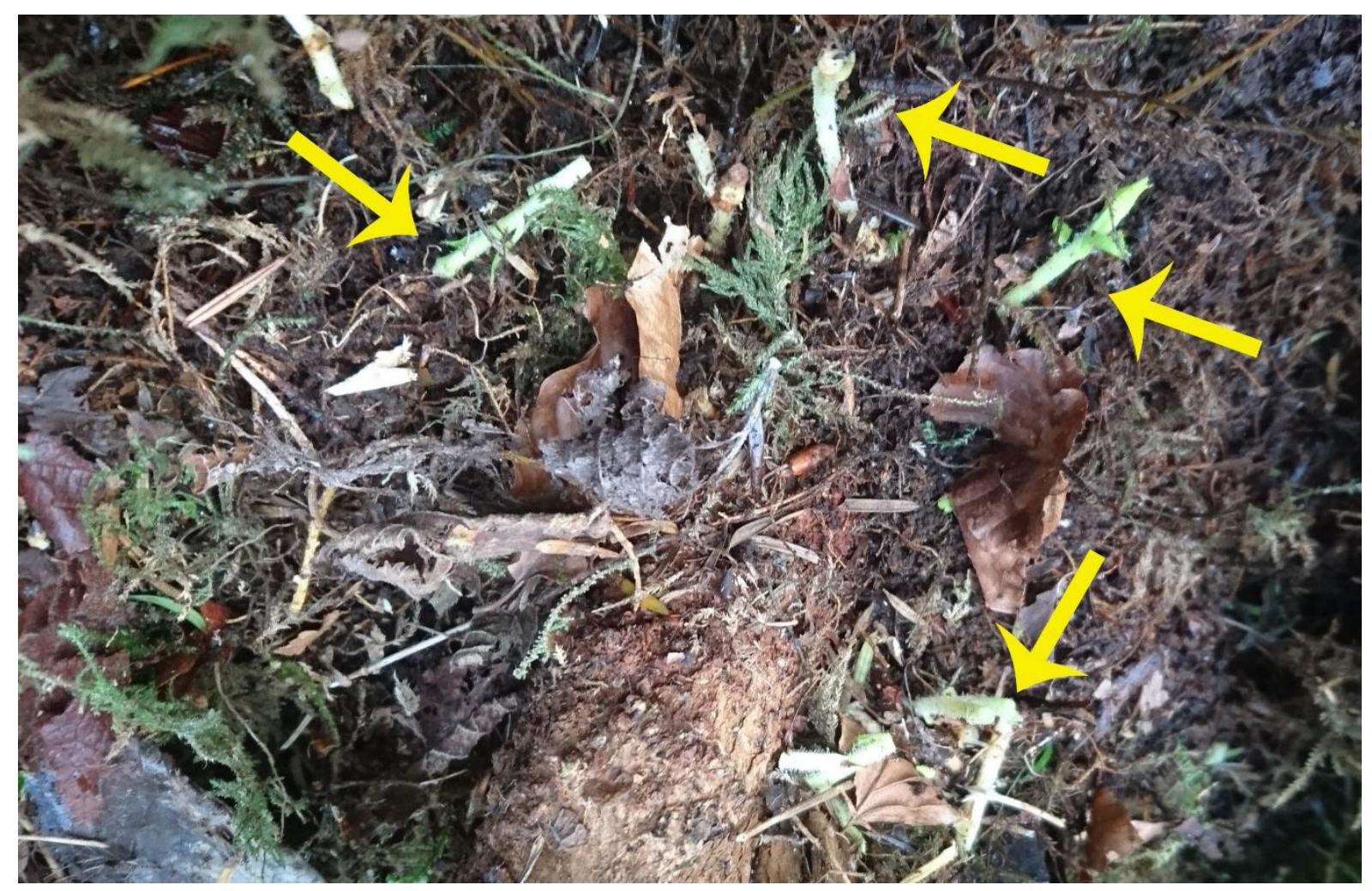

Figure 10. Young shoots of Arbutus unedo emerging from a lignotuber; the moss and litter layer has been cleared. Wolf Island, Lough Gill Co Sligo.

The ability of $A$. unedo to rapidly invade suitable new habitat was notable on Garinish Island, Co. Kerry. Over 100 comparatively young and even-aged individuals, with just one or a few small trunks and narrow bases had been struggling amidst Rhododendron, now recently cut back. These were invariably growing on one of the many rock outcrops or crags. It appeared that at some point in the comparatively recent past, $A$. unedo had invaded the eastern half of the island, but then Rhododendron had overwhelmed it, to cover most of the 35 ha. island. Two large $A$. unedo trees, overhanging the eastern seashore, one adjacent to the more recent jetty, may have been the original source for the others. Previously part of the Parknasilla estate, the island was sold to Lord Dunraven in 1855, who built a holiday home there (Stoakley, 1986), at which time grazing on the island ceased (S. Galvin pers. comm.).

An extensive search failed to find $A$. unedo on a north-facing cliff in the Gap of Dunloe, at $c .230 \mathrm{~m}$, the highest altitude for a specific record in Ireland (O'Malley, 2001). One explanation for its possible disappearance there is the exceptionally cold winter of 2009/10 in the west of Ireland. An altitude of $240 \mathrm{~m}$ in Co. Kerry would be at the January $4.5^{\circ} \mathrm{C}$ minimum temperature which Sealy (1949) calculated was its limit (applying the standard lapse rate of $0.98^{\circ} \mathrm{C} / \mathrm{m}$ ). 
In Co. Sligo, at its climatic limit, where there are currently just $32 \mathrm{~A}$. unedo trees around Lough Gill, its long-term survival seems precarious (Fig. 11). As well as shading threats, seedling establishment is extremely limited (Cotton \& Sheehy Skeffington, 2021). Exceptions may be three craggy islands along the south shore, and a sheltered cliff on the north shore, where individuals have remained constant since Praeger's survey (1932a). The only young tree found was on one of those craggy islands.

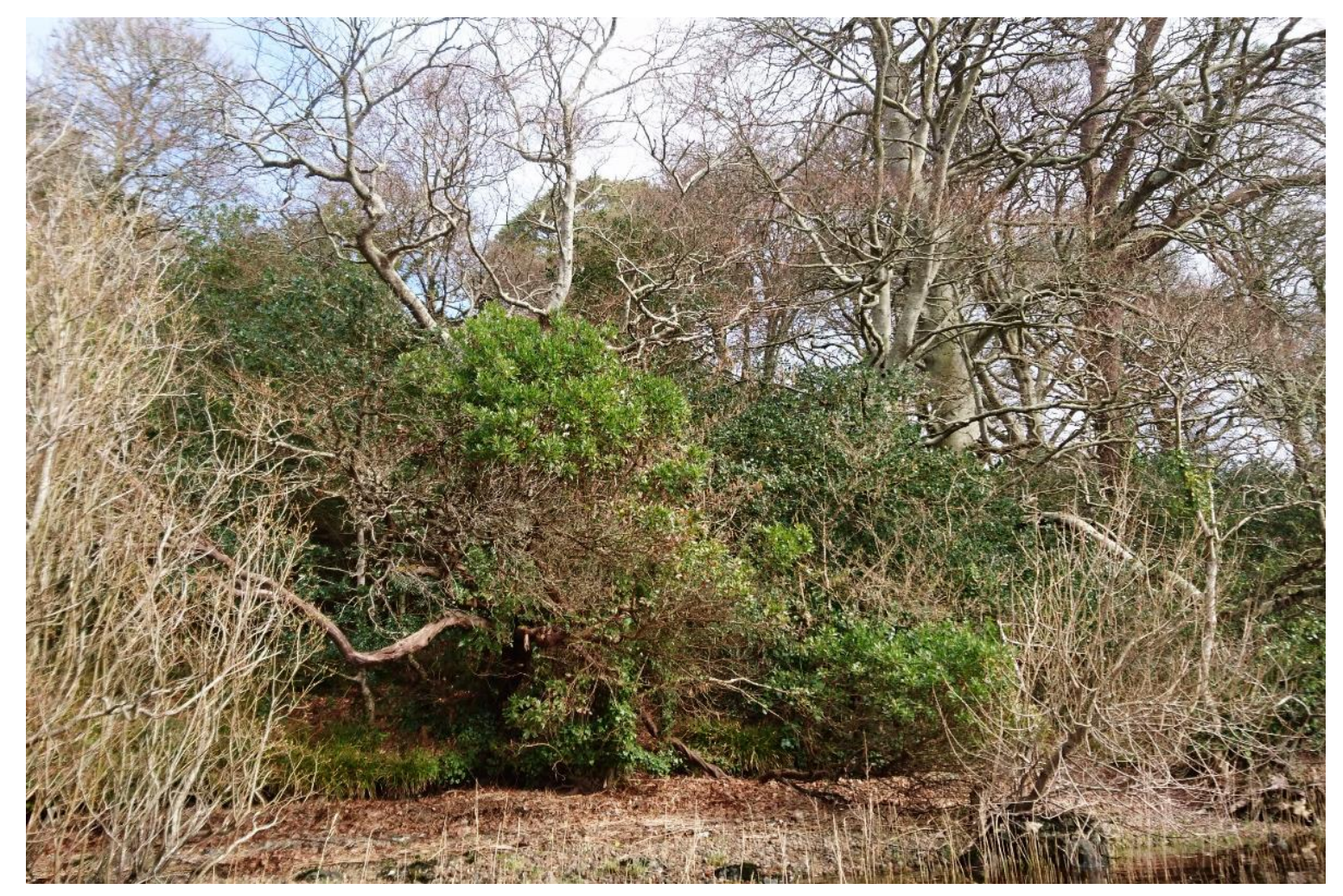

Figure 11. The last remaining Arbutus unedo leaning over the lakeshore, Church Island, Lough Gill, Co Sligo. The other four individuals seen there by Praeger (1932a) have died, overtopped by planted Fagus sylvatica and invading Taxus baccata.

\section{Irish placenames}

We visited the three places in Ireland outside the current $A$. unedo distribution that have names most likely to derive from the Irish caithne (Kelly, 1999; https://www.logainm.ie; see Appendix 1).

1. Derrynacaheny (Doire na caithne) 'Oak wood of the Arbutus'. Co. Clare. A small woodland remnant within what was once the Great Wood of Aughty which in Tudor times covered the south and south-west flanks of the Slieve Aughty mountains. Westropp (1908) lists it among some fifty such 'Derry' (Oak wood) names crowded along these flanks. The name appears on the first 6-inch Ordnance Survey map for Ireland of c.1829-1842 (https://map.geohive.ie).

The wood, along with several others nearby, is on a valley side and spring line associated with exposed shales, presumably left as woodland because of the unsuitably wet terrain. It is $c .500 \mathrm{~m}$ wide, on a steep south-facing slope with two 
large spring/seepages, surrounded by wet blanket bog and below, a very wet valleybottom field. Scattered with moss-covered boulders, the wood comprises semimature oaks, most with evidence of coppicing or pollarding. Other trees include ash, birch, holly and hazel.

It seems extremely unlikely to have ever contained $A$. unedo. There is no suitable habitat today; the canopy is dense, the woodland edge grazed, and the terrain very wet, with no cliffs or crag refugia. We could see no other habitat within the valley where $A$. unedo might have occurred, not least as, until comparatively recently, it was part of a large ancient wood.

\section{Ardcanny (Ard Caithne) 'Arbutus headland or hill', Co. Limerick.}

This comprises a townland and ruined church beside the Shannon Estuary for which historical references date to the c.1200 Black Book of Limerick which refers to it as Arcatny or Ardcathni and the 1306 'papal taxation' which lists it as Ardcathny (https://www.logainm.ie/en/1499?s=ardcanny). The form of the name, without the article $n a$, dates to before the $9^{\text {th }}$ century (P. O Cearbhall, pers. comm.). A series of low drumlins are adjacent to an exposed rocky foreshore that forms a peninsula of harder sandstone, where the River Maigue enters the Shannon. When most journeys were made by boat, this site could have been significant. Ard means 'height' or 'hill', but Aird meaning 'headland' might refer to the rocky peninsula (P. Ó Cearbhall, pers. comm.). There are no potential refuge sites for $A$. unedo, though it could grow on the well-drained drumlin soils.

\section{Smerwick Harbour (Ard na Caithne) 'Hill of the Arbutus', Co. Kerry.} This is a large cove forming a natural harbour on the north of the Dingle peninsula. Smerwick is a Viking name meaning 'butter port'. The Irish name was first recorded (as Ardnecanny) in 1584 in the Desmond Survey (https://www.logainm.ie/en/22598?s=Ard+na+Caithne). A. unedo would not grow on the wet boggy soils, but there are many suitable cliff ledges around the cove, particularly on the two headlands.

Great Orme, Caernarvonshire, $N$ Wales (v.c.49)

We visited the Great Orme, a limestone headland $c .200 \mathrm{~m}$ high with steep slopes and cliffs, on the north Wales coast, because $A$. unedo is recorded as invasive there (Proctor, 2002). The shallow stony soils support a rich limestone flora, managed for conservation as open commonage with sheep. $A$. unedo was previously confined to a patch of woodland on the southern slope, adjacent to the Haulfre Gardens, where it was not considered native, or recorded until 1994 (BSBI Distribution Database). When grazing near the wood ceased, $A$. unedo invaded along with other shrub species, threatening the protected grassland flora (Fig. 12). Country Park staff now control these with cutting and herbicides.

Within the woodland, $A$. unedo is tall, often struggling for light. Two larger trees on two small south-facing cliff ledges, were multi-stemmed, with wide bases and dead wood and very unlikely to have been planted. One, recently cut back, was regrowing. No others like this were found in the wood or garden. They are $1 \mathrm{~km}$ from a large Bronze Age copper mine (Dutton et al., 2014). Their position on a cliff ledge, avoiding overshadowing and grazing is similar to where ancient trees survive in Ireland. The south-facing aspect could help survival from frost, at a latitude 
halfway between that of Co. Kerry and Co. Sligo. We saw no other suitable cliffs on the southern face of the Great Orme or nearer the mine site.

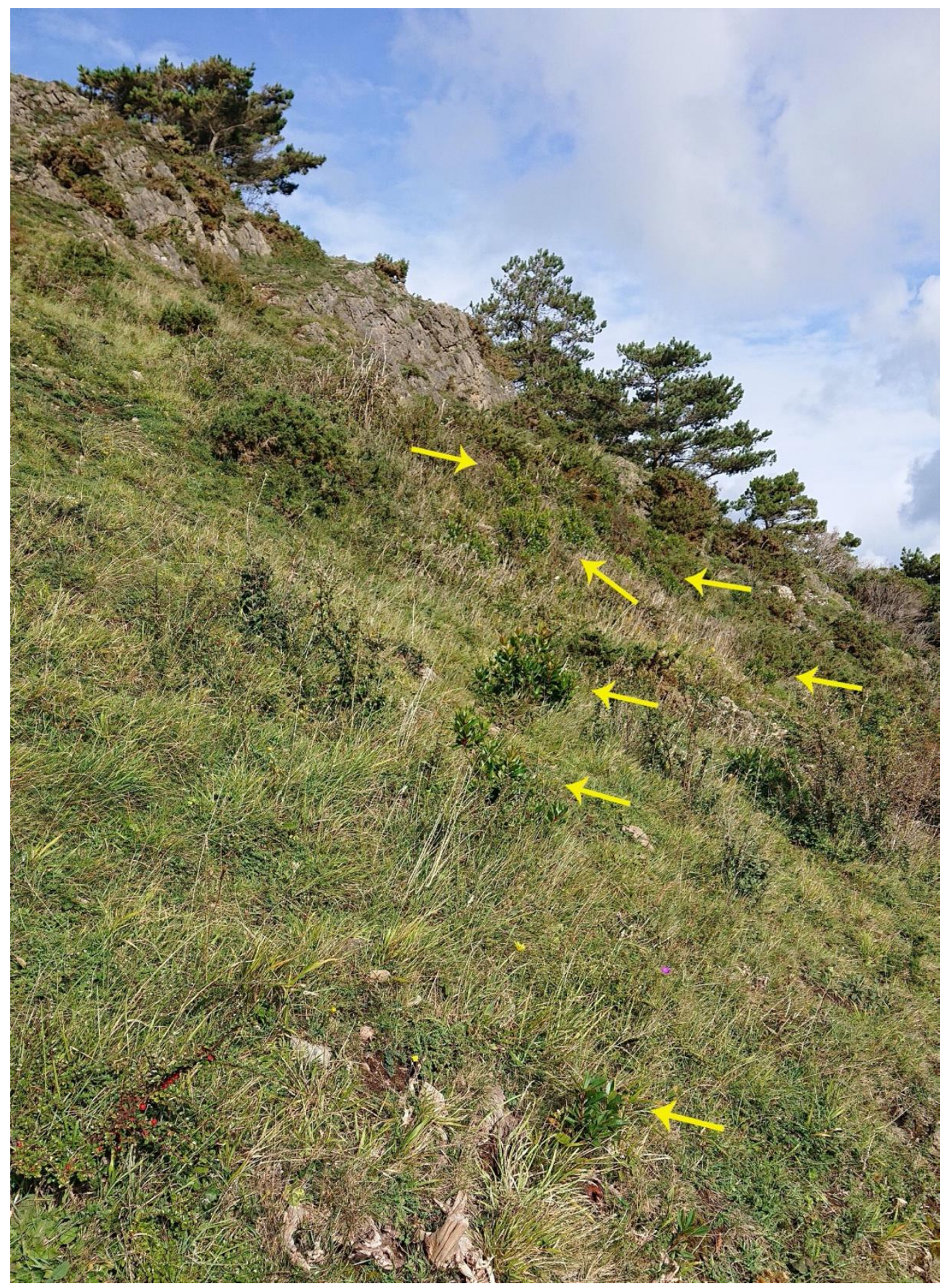

Figure 12. Arbutus unedo invading grassland following the removal of grazing on the Great Orme, $\mathbf{N}$ Wales.

\section{Discussion}

The genetic results for the $A$. unedo population sampled at Killarney (Santiso et al., 2016) indicate that the species came from the Iberian Peninsula and did not arrive in Ireland by overland migration after the last glaciation. Such a migration would have 
produced unique genetic haplotypes and would most likely have been via western France, where, however, the sampled population was genetically different. As only one population from Ireland was sampled, the results must be viewed with caution, yet combined with the other information about $A$. unedo in Ireland, they are very compelling.

There is no apparent ecological reason why $A$. unedo, if native, should not occur more widely at least in south-west Ireland, as there are widespread suitable habitats and refuges there, and between the Kerry/West Cork and Sligo populations. This limited and anomalous distribution reflects that of other Hiberno-Lusitanian species, now considered to be introduced (Foss \& Doyle, 1990; Sheehy Skeffington and Van Doorslaer, 2015; Lupton \& Sheehy Skeffington, 2020).

$A$. unedo is favoured by disturbance, including human activity, as are many pioneer species. Its pollen curves show short spikes or more prolonged increases in response to woodland disturbance attributed to human activity (Mitchell, 1990; 1993). After such disturbance, its pollen amounts eventually return to a level similar to that found today, where it is mostly confined to refuges away from shading or grazing.

However, given the right situation, such as on the Great Orme, without grazing or shading on well-drained soils in a relatively mild climate, it can invade rapidly. This ability, combined with its ability to regenerate trunks so readily, means $A$. unedo would have been strongly favoured by repeated cutting back of woodland. At the Ross Island mine such regular cutting of the surrounding woodland occurred for some 500 years from c.2400 BC (O'Brien, 2004).

The oldest fossil records for $A$. unedo in Ireland are from the Killarney area; from Lough Leane, where $A$. unedo charcoal was found in the upper horizon 2200 1900 BC, of two horizons associated with mining at Ross Island (O'Brien, 2004) and from above the Upper Lake (Vokes, 1966), where one pollen grain was roughly dated within this range at $c .4,000$ years ago (Mitchell \& Watts, 1970).

These records do not exclude the possibility that $A$. unedo was already present in south-west Ireland and invaded the disturbed woodland from a local refuge. However, since archaeologists believe it likely that the Ross Island copper mining and smelting was undertaken by a new community, or at least by technicians with this expertise who came from elsewhere (O'Brien, 2004), this would provide a possible means for the introduction of $A$. unedo at that time. If this occurred towards the start of the mining at Ross Island $(c .2400 \mathrm{BC}), A$. unedo would have had enough time to spread within the disturbed woodland from introduced individuals to become established sufficiently to appear in pollen and charcoal records some 200 years later.

The nearest copper mining and smelting known in Europe at the time the Ross Island mining began was in northern Iberia (O'Brien, 2015). Widespread and intensive copper mining occurred in the central Cantabrian mountains of Asturias and León, including three large mines, chiefly active between 2600 and 2300 BC (Blas Cortina, 2010; O'Brien, 2015). There is also a prehistoric copper mine active from $2500 \mathrm{BC}$ in the foothills of the Atlantic Pyrenees (Beyrie \& Kammenthaler, 2008). Significantly, the Ross Island stone hammers are closest in form to those of the Cantabrian mines (O'Brien, 2015). A. unedo occurs sporadically along the northern coast of the Iberian Peninsula, often penetrating south into the mountains (http://www.anthos.es, Blanco et al., 1997). The $A$. unedo population sampled by 
Santiso et al. (2016), which showed no apparent genetic difference to that from Killarney, was sampled near San Sebastián in northern Iberia (Fig. 4), which lies between these two ancient copper mining areas.

\section{Potential uses of $A$. unedo in the past}

A. unedo has been found as charcoal in Chalcolithic and Bronze Age sites in Portugal where it is known for its calorific value and as good kindling (Queiroz, 2009; 2010) and is thought to have been selectively used for this as early as the Neolithic in Provence, France (Delhon et al., 2017). Though $A$. unedo is slow growing, producing good charcoal, there is no evidence for its use in the mining and smelting process at Ross Island, rather its occurrence was in charcoal found away from these activities (Van Rijn, 2004). In fact, the importing of a species by the miners specifically to provide charcoal for smelting seems unlikely, as it would be a long time before it could produce the quantity needed.

If $A$. unedo was introduced by the first miners, it could have been brought as a food source, or even because the tree or fruit were important to their mining culture and/or tradition. Perhaps significantly, $A$. unedo naturally produces alcohol in mature berries, even on the tree, and is commonly used in Mediterranean countries as a source of alcohol. Today it is distilled for brandy, but the initial process is very simple and could have been practiced by early communities; ripe berries, picked directly from the tree, are placed in a pot with a little water, mashed, and left for several months. As with traditional wine production, no sugar or yeast source are used (Cavaco et al., 2007).

The introduction of $A$. unedo by a people new to Ireland that uses its berries, and who settled on the shores of Lough Leane, having come from somewhere more sophisticated, is described remarkably precisely in the tale of Diarmaid and Gráinne, where the Tuatha Dé Danann brought with them 'crimson nuts, arbutus berries and sweet berries'. It is even possible to suggest that the crimson nuts might have been sweet chestnut Castanea sativa which is an important food source where $A$. unedo is native, including the Cantabrian mountains of northern Iberia (Blanco et al., 1997; Conedera et al., 2016). It grows well in South-west Ireland on well-drained soils, but there is no fossil record for it and unlike $A$. unedo, it is not invasive there, so is unlikely to have survived an early introduction.

\section{Spread of $\underline{A}$. unedo from Lough Leane}

The only pollen evidence to date for the presence of $A$. unedo on the Beara Peninsula dates back to $c .2000 \mathrm{BP}$, in the short core at Lough Inchiquin (Mitchell, 1993; Fig. 6). This dates after the Middle Bronze Age spread south and west of copper mining and smelting into the Beara Peninsula and beyond (O'Brien, 2012; 2015). Any records for $A$. unedo trees in south-west Ireland are confined to the area within which Bronze Age copper mining is known to have occurred and all but the cluster that includes $\mathrm{L}$. Inchiquin have a proposed Bronze Age copper mine nearby, usually on a mountainside.

However, this apparently strong correlation is not simple, as, conversely, many of the dated Bronze Age copper mines in West Cork have no associated $A$. unedo, even in the pollen cores from near Mount Gabriel (Mighall et al., 2000). As A. unedo is very rare in pollen diagrams, only found in cores where it occurs immediately nearby (Mitchell, 1993), it might still have been in the vicinity. But its virtual absence today 
from much of the Mizen Peninsula, where so many Bronze Age copper mines have been found, is not so easily explained.

However, $A$. unedo could once have been more widespread on the Mizen Peninsula but has not survived because the terrain is different to that of the Beara and Iveragh peninsulas, with less suitable cliff or crag refuges, or lakes with craggy islands. Bishop Dive Downes reported in 1700 that Mount Gabriel had 'no trees, no shelter' (Brady, 1863), as is the case today. Only on the rocky far west of the Mizen Peninsula do a few $A$. unedo survive: on cliffs at Crookhaven and Ballyrisode, the former recorded as early as 1699 (Brady, 1863).

Alternatively, $A$. unedo may have never reached as far as Mount Gabriel, since the Mizen Peninsula is further from Lough Leane. The Crookhaven and Ballyrisode mines, further west, began earlier (2009 BC and $1853 \mathrm{BC}$ respectively) than those at Mount Gabriel (1700 BC) (O'Brien, 2015). The mines at Crookhaven, beside a deep inlet at the south-westernmost point of Ireland, could have been worked by a community coming from the sea, who might have later exploited the inland Mount Gabriel mines.

\section{Coppicing as a means of $\underline{A}$, unedo spread}

Bronze Age copper production consumed timber both for fire-setting in the mining process and as charcoal for the smelting, the quantities for which have been calculated to be 'huge' (O'Brien, 2012). However, pollen diagrams for cores examined near several Bronze Age mining sites fail to show the expected 'disturbance' of woodland for the relevant dates (Mighall \& Chambers, 1993; Mighall et al., 2000), leading Mighall et al. (2000) to conclude that the woodland was managed as coppice. Coppicing on a rotation to supply continuous firewood would maintain woodland and its pollen production but would also strongly select for a pioneer tree species that regrows very easily from its base, such as $A$. unedo.

With so much ideal habitat for $A$. unedo to invade and flourish in during the working period of each mine, it is possible that the distribution of $A$. unedo we see today reflects the extent of the areas which were coppiced for copper mining. Its spread from Lough Leane could have simply been accidental, carried to each new site by people for food or by birds.

If $A$. unedo did spread with the copper mining activity, carried accidently or deliberately, it is unlikely to occur close to where the mining communities lived, which would have been open agricultural land where crags and cliffs would be rare. Instead, $A$. unedo would occur near where woodland was coppiced for fuel. This appears to be the case with each cluster of records, as e.g. at Hungry Hill/Adrigole (Fig. 8), where the copper mine is on the mountainside, but any settlement would have been in the Adrigole valley surrounded by farmed land; the valley sides might have been left as woodland from which the firewood was cut. Thus, the current $A$. unedo distribution there encircles the valley, with post-1950 records occurring on mountain and sea cliffs as well as around a lake (pre-1950 records are not so sitespecific).

The separation of the woodland and agricultural lands might account for some gaps in $A$. unedo distribution, such as in the low-lying area between Loughs Leane and Guitane (Fig. 7), which is good agricultural land. A pollen core taken at Sheheree Bog nearby, showed woodland clearance and sustained human activity over the period of mining at Ross Island, suggesting this was where the mining 
community lived (Mitchell \& Cooney, 2004), but unlike cores sampled by Lough Leane (e.g. Mitchell, 1988), it had no A. unedo pollen.

\section{Recent changes and coppicing}

The widely repeated belief that $A$. unedo has declined in extent in south-west Ireland due to preferential cutting for firewood or charcoal in the $16^{\text {th }}$ to $18^{\text {th }}$ centuries (e.g. Scully, 1916) is not supported by the pollen evidence. On the contrary, the proportion of $A$. unedo pollen in the Lough Inchiquin core (Fig. 6) markedly increased over this period. Indeed, every core in south-west Ireland with A. unedo pollen has its maximum peak from c.1750 -1800 A.D. (Mitchell, 1993). This disparity is probably because the woodland was coppiced for the smelting and to the untrained eye, woodland managed on a short coppicing cycle to produce 'roundwood' (Hodgkinson, 2009) would not look like woodland, but would, in fact, favour $A$. unedo.

However, with the eventual abandoning of the coppicing, the trees would then grow into canopy forest such as around Lough Leane, to the detriment of $A$. unedo (Mitchell, 1990). This would also be true for the clearing and replanting of woodland that also occurred during this period (Radcliff, 1814) which would allow a more temporary invasion of $A$. unedo and then exclude it. The ending of this expansion cycle explains why many of the remaining $A$. unedo in Co. Kerry appeared 'senescent' by the end of the $19^{\text {th }}$ century (Scully, 1916).

Grazing pressure also increased considerably in recent centuries, as domestic stock and sika deer were added to the native red deer (Kelly, 1981), so that today most of south-west Ireland, except around Killarney, is an open landscape containing few pockets of woodland and trees only occur where they are inaccessible to grazers.

Thus, $A$. unedo remains today where it is free from both shade and grazing, often on crags or cliffs. Such sites have provided long term refuges from which it could potentially reinvade in the right conditions. This cycle of $A$. unedo expansion and contraction is clearly illustrated in the Lough Inchiquin pollen diagram (Fig. 6). A. unedo increases markedly twice, firstly over a short period in the Bronze Age in response to a major disturbance marked by an increase in charcoal and decrease in tree pollen, and secondly during the last three hundred years, during the period of coppicing and replanting in Co. Kerry. The second increase in $A$. unedo pollen is much more prolonged but still eventually decreases to the same base line.

\section{Spread by Estates}

Arbutus unedo has long been a popular ornamental tree and is known to have been sent as gifts to English statesmen as early as the 1580s from 'one part of Munster' (Watts, 1984). Estates in Ireland must also have planted $A$. unedo as ornamental trees from where it might have spread, which may explain its presence at Parknasilla and nearby Garinish Island in Co. Kerry, as part of the Derryquin Estate founded by the Blands, Vicars of Killarney. 


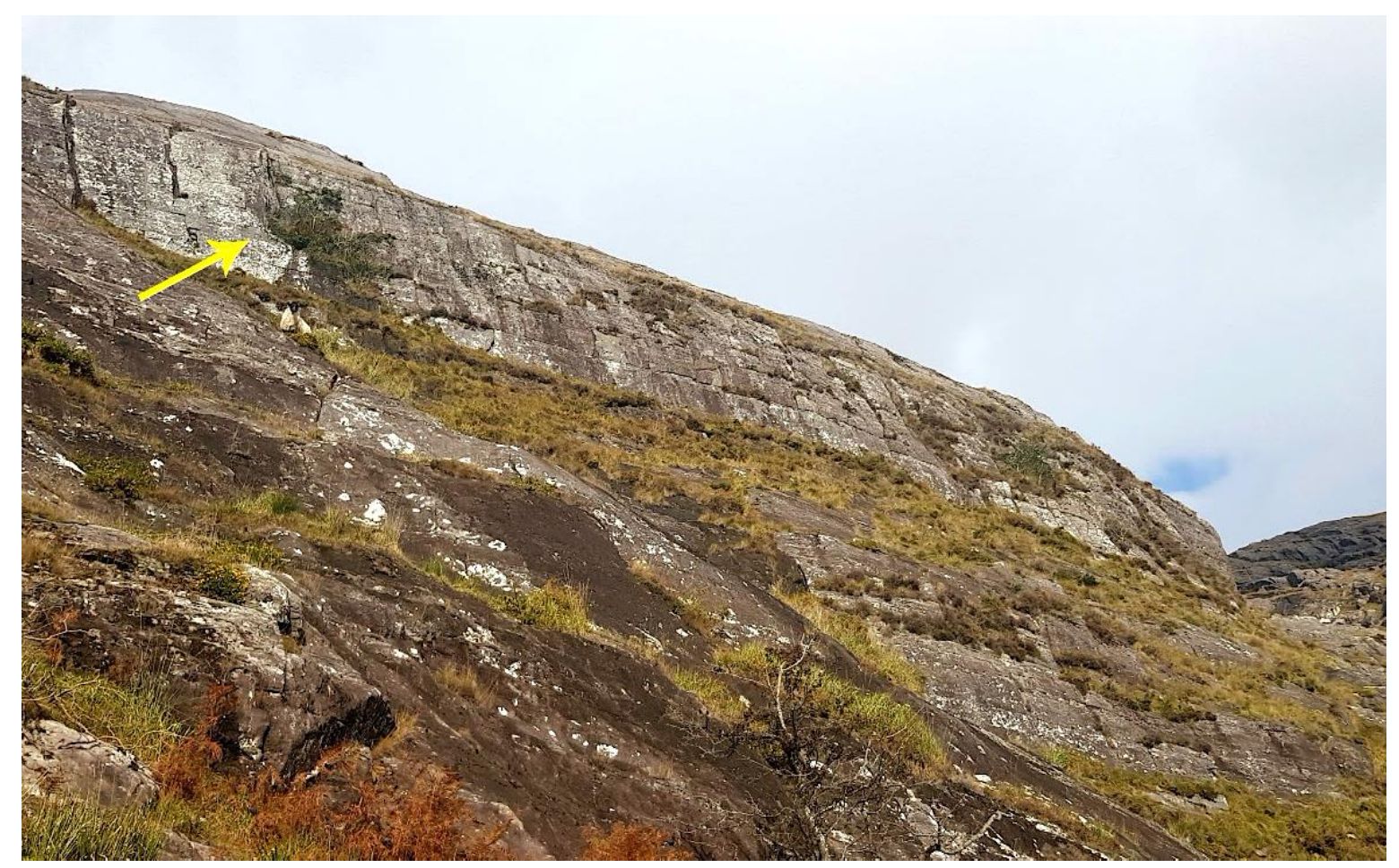

Figure 13. Arbutus unedo surviving on an inaccessible cliff ledge on grazed commonage on the side of Adrigole Mountain, Co Cork. Image: Clare Heardman

\section{Sligo population}

Such an introduction by an estate could also account for the population around Lough Gill, Co Sligo. Hazelwood House was built near the lake in 1727-1731 and is known to have many planted exotic species including Arbutus andrachne (no longer present today) (Wynne, 1860). A. unedo is also mentioned but it is unclear whether it had been planted or was already present on the nearby lake.

The estimated ages of the oldest trees on Lough Gill (Cotton \& Sheehy Skeffington, 2021) would allow for an introduction soon after Hazelwood House was built, and the central position of the house relative to the small $A$. unedo population around the lake makes this explanation attractive. However, the discovery of small quantities of $A$. unedo pollen dated to $c .1,900$ years ago in cores from just outside its present distribution on Lough Gill (Dodson \& Bradshaw, 1987) is at odds with this and would suggest that it has had a long-term more widespread presence there. If so, this could have contracted during some of the exceptionally cold spells, many of which are recorded between c.600 and $1900 \mathrm{AD}$ (Hickey, 2011). A. unedo is at the predicted limit of its distribution in Sligo, so that it would be particularly sensitive to a worsening climate and could have been killed everywhere except by the lake shore (Cotton \& Sheehy Skeffington, 2021).

The possibility that $A$. unedo once occurred beyond its present distribution, beside small lakes to the west of Lough Gill (Dodson \& Bradshaw, 1987) which have suitable crag refuges, might suggest that its original introduction was via Ballysadare Bay. The only mine suggested as possibly ancient in Co. Sligo (Timoney, 2002) occurs by the shore there (Fig. 9). However, this is a lead and silver mine and there is no evidence for Bronze Age lead and silver mining in Ireland, nor any other later 
mining connection with $A$. unedo. Full details of all possibly relevant features are given on the online map for $A$. unedo in Co. Sligo.

\section{Placenames}

There are only two accepted Irish placenames referring to $A$. unedo outside its present range where we consider $A$. unedo could feasibly have once occurred. Significantly, both are on the coast: one on the Dingle Peninsula, one on the Shannon estuary. If $A$. unedo was there at some point, it could have been brought by sea, as could the Sligo population, either from the populations in Kerry and W Cork or as separate introductions from elsewhere.

\section{Great Orme}

The occurrence of an $A$. unedo population on the Great Orme in north Wales, notably with two old multi-trunked trees on cliff ledges within a kilometre of a Bronze Age copper mine, appears significant, as this mine eventually succeeded Ross Island as the principal copper source in Britain and Ireland (Timberlake, 2014; O'Brien, 2015). However, A. unedo was not recorded there until 1994 (BSBI

Distribution Database) while the Great Orme has long been known as an interesting botanical site, so one might expect that $A$. unedo would have been noted. But early botanists rarely recorded plants regarded as escapees, so the possibility that this is an ancient population cannot be entirely dismissed.

It is also possible that the $A$. unedo populations on the coasts of Brittany are related in some way to the one at Lough Leane. Botanical descriptions (des Abbayes et al., 1971) suggest these also appear to be relict populations holding on in refuge sites. Brittany is believed by archaeologists to be important in the spread of early Bronze Age culture but did not have copper mining (O'Brien, 2015).

\section{Further work}

Ultimately, it is archaeological research which will place our results in the context of what is known about Bronze Age activities. This paper simply suggests a route for how copper smelting may have come to Ireland at Ross Island, the first known place in north-western Europe where such activity occurred. The results also indicate that this technology may have stayed with a specific community somehow associated with $A$. unedo when copper mining and smelting spread elsewhere in south-west Ireland, and possibly even to Wales.

Further genetic investigation is needed to confirm our hypothesis that would include other populations in south-west Ireland, Co. Sligo and North Wales, as well as populations in western France and northern Iberia. Such an investigation could also reveal how closely related the Irish, Great Orme, and Brittany populations are to those near the ancient mines in northern Iberia. However, this needs to be complemented by palynological studies at some locations, particularly at the Great Orme, since it is known that plants from Ireland were exported to the UK for horticulture from as early as 1586 (Watts, 1984).

Should such a genetic study give further support to the theory that $A$. unedo was introduced to Ireland directly from northern Iberia, then it would be one more of Ireland's Lusitanian species thought to have been introduced by humans after the last ice age from the Iberian peninsula, such as the Kerry slug, Geomalacus maculosus (Reich et al.,2015), Irish heath, Erica erigena (Foss and Doyle, 1988, 
1990), and Mackay's heath, Erica mackayana (Sheehy Skeffington and Van Doorslaer, 2015).

The heathers were probably introduced within the last five hundred years, and it is not possible to date the introduction of the Kerry slug, but the $A$. unedo evidence suggests human introduction over 4,000 years ago. There are several other Lusitanian plant species, clearly unable to have survived the last glaciation in Ireland, which have their nearest main population in northern Iberia, but which are today too widespread to have been introduced in the historical past, such as Pinguicula grandiflora, Large-flowered Butterwort, and Daboecia cantabrica, St Dabeoc's Heath. Their disjunct Irish distributions are also often anomalous. If $A$. unedo can be carried directly to Ireland from the Iberian Peninsula, c.4,400 years ago, then direct sea journeys could also be the way these species were introduced long enough ago to have spread throughout their current range.

\section{Conclusion}

Arbutus unedo is probably not a native species to Ireland but is an ancient archaeophyte introduced more than 4,000 years ago to beside Lough Leane Co. Kerry from northern Iberia by miners that came there to extract the copper. When and how it subsequently spread to the other stations regarded as native in Ireland is not fully clear. It appears that the spread in south-west Ireland is related to the subsequent movement of copper mining, but not in Co. Sligo. The oft repeated notion that $A$. unedo was once more widely distributed in Ireland and declined due to preferential cutting for firewood is not tenable, but there are two places on the west coast of Ireland where Irish place names indicate it could have occurred at one time.

Wider genetic studies, alongside palynological work recording when $A$. unedo pollen first appears in the fossil record, are needed. Such studies, as well as the identification of any further potentially relict populations of $A$. unedo elsewhere in Britain and Ireland, have the potential to provide valuable evidence for the past movement of peoples in the Chalcolithic and Early Bronze Ages.

\section{Acknowledgements}

We are especially grateful to the three BSBI Irish Vice-county Recorders, Rory Hodd (v.c.H1 \& H2), Clare Heardman (v.c.H3) and Don Cotton (v.c.H28), for all their help with the current distribution of $A$. unedo, including field work checking records for us, and to Wendy McCarthy, Vice-county Recorder for Caernarvonshire (v.c.49), for showing us $A$. unedo on the Great Orme. We are thankful to Fraser Mitchell and Richard Bradshaw for supplying information and fossil pollen record dates; to Mike Wyse Jackson, Mike O'Sullivan, James O'Shea (Derrynane House), Mary Sheehan \& Seán Forde (Killarney National Park), Séamus Galvin (Garinish Island) and Eoghan Daltún, for help with finding $A$. unedo; Padraic de Bhaldraithe for advice on folklore and directing us to Tóraíocht Dhiarmada agus Ghráinne; Pádraig Ó Cearbhall and Aindí Mac Giolla Chomhghaill for help with Irish placenames; Ajahn Appamado and David Holyoak for information on the uses and ecology of $A$. unedo in Portugal; Michael O'Connell for information on vegetation history; Bob Quinn for historical leads and discussion. Many thanks to Paul Gosling, Sam Moore and William O'Brien for very useful discussion, information and guidance about the relevant archaeology. We are indebted to Jaime Fagúndez Díaz for helping us understand genetic research 
relevant to Irish Lusitanian species and telling us of the key work on $A$. unedo that inspired our research (which as it does not have $A$. unedo in its title we might have never found). Daniel Kelly, Paul Gosling, Jaime Fagúndez Díaz, Clare Heardman and Rory Hodd gave very useful suggestions on an earlier draft of this paper.

\section{References}

des Abbayes, H., Claustres, G., Corillion, R. \& Dupont, P. 1971. Flore et Végétation du Massif Armoricain. I Flore Vasculaire. Saint-Brieuc: Presses Universitaires de Bretagne.

Anon. 2003. What Beara was like 300 years ago. Available at: <http://www.irishidentity.com/extras/clergy/stories/beara.htm>

Beatty, G.E. \& Provan, J. 2013. Post-glacial dispersal, rather than in situ glacial survival, best explains the disjunct distribution of the Lusitanian plant species Daboecia cantabrica (Ericaceae). Journal of Biogeography 40: 335-344.

Beyrie, A. \& Kammenthaler, E. 2008. Aux origines de l'activité minière dans les Pyrénées occidentales. L'exploitation du cuivre, du fer, de l'or et de l'argent. Available at:

$<$ https://www.geolval.fr/images/Geoval/sorties/2017/Sortie 05/MINESFER LARLA 6961 fichier dossier22-beyrie.pdf>

Birks, H.J.B. 1989. Holocene Isochrone Maps and Patterns of Tree-Spreading in the British Isles. Journal of Biogeography 16 (6): 503-540.

Blanco, E., Casado, M.A., Costa, M., Escribano, R., García, M., Génova, M., Gómez, A., Gómez, F., Moreno, J.C., Moria, C., Regato, P. \& Sainz, H. 1997. Los Bosques Ibéricos: Una Interpretación Geobotánica. Barcelona: Editorial Planeta.

Blas Cortina, M.Á. de \& Suárez Fernández, M. 2010. La minería subterránea del cobre en Asturias: un capítulo esencial en la prehistoria reciente del norte de España. In: Blas Cortina, M.Á. De, Delibes de Castro, G., Villa Valdes, A. \& Suárez Fernández, M., eds. Cobre y Oro. Minería y Metalurgia en la Asturias Prehistórica y Antigua: 43-82. Oviedo: Real Instituto de Estudios Asturianos.

Bonfils, P. 1990. Quelques définitions dans le language courant. Forêt méditerranéenne XII, n०4: 523.

Brady, W.M. 1863. Clerical and Parochial Records of Cork, Cloyne and Ross. Vol 1. Dublin: Alexander Thom.

BSBI Distribution Database [accessed 24 March 2021]. Available at: $<$ https://database.bsbi.org/>

Caudullo G., Welk, E. \& San-Miguel-Ayanz, J. 2017. Chorological data for the main European woody species. Data in Brief, 12: 662-666. Available at: $<$ doi.org/10.1016/j.dib.2017.05.007>.

Data: <https://doi.org/10.6084/m9.figshare.5100736>

Cavaco, T., Longuinho, C., Quintas, C. \& Saraiva De Carvalho, I. 2007. Chemical and microbial changes during the natural fermentation of strawberry tree (Arbutus unedo L.) fruits. Journal of Food Biochemistry 31: 715-725.

Clark, C.D., Hughes, A.L.C., Greenwood, S.L., Jordan, C. \& Sejrup, H.P. 2012. Pattern and timing of retreat of the last British-Irish Ice Sheet. Quaternary Science Reviews 44: 112-146.

Conedera, M., Tinner, W., Krebs, P., de Rigo, D., Caudullo, G., 2016. Castanea sativa in Europe: distribution, habitat, usage and threats. In: San-Miguel-Ayanz, J., de 
Rigo, D., Caudullo, G., Houston Durrant, T. \& Mauri, A., eds. European Atlas of Forest Tree Species. 78-79. Luxembourg: EU Public Office.

Cotton, D. \& Sheehy Skeffington, M. 2021. Distribution of the Strawberry Tree (Arbutus unedo L.) around Lough Gill, County Sligo. Sligo Field Club Journal 7: 169-196.

Cunliffe, B. 2010. Celticization from the West: the contribution of archaeology. In: Cunliffe, B. \& Koch, J.T., eds. Celtic from the West. 13-38. Oxford: Oxbow Books.

Cunliffe, B. \& Koch, J. T., eds. 2010. Celtic from the West. Oxford: Oxbow Books.

Delhon, C., Moreau, C., Magnin, F. \& Howarth. L. 2017. Rotten posts and selected fuel: Charcoal analysis of the first Middle Neolithic village identified in Provence (Cazan-Le Clos du Moulin, Vernegues, Bouches du Rhône, South of France). Quaternary International 458: 1-13.

Dodson, J.R., \& Bradshaw, R.H.W. 1987. A history of vegetation and fire, $6600 \mathrm{BP}$ to present, County Sligo, western Ireland. Boreas 16 (2): 113-123.

Dutton, A., Fasham, P.J., Jenkins, D.A. \& Caseldine, A. 2014. Prehistoric Copper Mining on the Great Orme, Llandudno, Gwynedd. Proceedings of the Prehistoric Society 60 (1): 245-286.

Forbes, E. 1846. On the connexion between the distribution of the existing fauna and flora of the British Isles, and the geological changes which have affected their areas, especially during the epoch of the Northern Drift. Memoirs of the Geological Survey of Great Britain, and of the Museum of Economic Geology 1: 336-432.

Foss, P.J. \& Doyle, G.J. 1990. The history of Erica erigena R. Ross, an Irish plant with a disjunct European distribution. Journal of Quaternary Science 5(1): 1-16.

Foss, P. J. \& Doyle, G.J. 1988. Why has Erica erigena (the Irish Heather) a markedly disjunct distribution in Europe? Plants Today 1(5): 161-8.

Garvey, L.M. \& Flynn, D.P. 1995. Distribution of the strawberry tree Arbutus unedo at its lesser stations in southwest Ireland. Bulletin of the British Ecological Society 26(2): 87-92.

Godwin, H. 1975. The History of the British Flora. Cambridge: Cambridge University Press.

Green, J.A. 2007. Bryn Euryn, Colwyn Bay, Denbighshire (v.c.50) $1^{\text {st }}$ July. Field Meeting Reports -2006, BSBI News 104: 62-63.

Hackney, P. 1998. "Wild" Strawberry-trees (Arbutus unedo) in Co. Down v.c.H38. Irish Botanical News 8: 11-12.

Hall, M. 2011. The wild arbutus tree of Beara. Journal of the Cork Historical and Archaeological Society 116: 109-119.

Henry, A.H. 1908. Arbutus unedo, Strawberry tree. In: Elwes, H.J. \& Henry, A.H. The Trees of Great Britain \& Ireland. Edinburgh: R. \& R. Clark Ltd. (Republished by SR Publishers Ltd., Edinburgh. 1970).

Hétier, J-P. 1994. Éléments pour une gestion écologique des espaces forestiers littoraux et arrière-littoraux méditerranéens. Forêt méditerranéenne $\mathrm{XV}, \mathrm{n}^{\circ} 1$ : 97-102.

Hewitt, G.M. 1999. Post-glacial re-colonization of European biota. Biological Journal of the Linnean Society 68: 87-112.

Hickey, K. 2011. The historic record of cold spells in Ireland. Irish Geography 44: 303-321. 
Hodgkinson, J. S. 2009. The Wealden Iron Industry. Stroud: The History Press. Joyce, P.W. 1875. The origin and history of Irish names of places ( $2^{\text {nd }}$ Series). Dublin: McGlashan \& Gill.

Kelleher, C.T. 2013. In search of the origins of Ireland's Arctic and Mediterranean plants. In: Jebb, M. \& Crowley, C., eds. Secrets of the Irish Landscape: 39-45. Cork: Atrium.

Kelly, D.L. 1981. The native forest vegetation of Killarney, south-west Ireland: an ecological account. Journal of Ecology 69 (2): 437-472.

Kelly, F. 1976. The Old Irish tree-list. Celtica 11: 107-124.

Kelly, F. 1999. Trees in early Ireland. Irish Forestry 56 (1): 39-57.

Lanting, J.N. 2004. Ross Island: Radiocarbon dates and absolute chronology. In: O'Brien W., ed. Ross Island. Mining, Metal and Society in Early Ireland. Bronze Age Studies 6: 305-316. Galway: National University of Ireland Galway.

Little, D.J, Mitchell, F.J.G., von Engelbrechten, S. \& Farrell, E.P. 1996. Assessment of the impact of past disturbance and prehistoric Pinus sy/vestris on vegetation dynamics and soil development in Uragh Wood, SW Ireland. The Holocene 6 (1): 90-99.

Lupton, D. \& Sheehy Skeffington, M. 2020. A review of the ecology and status of the Kerry Lily Simethis mattiazzii (S. planifolia) Asphodelaceae in Ireland. British \& Irish Botany 2 (4): 309-334.

M'Enery, J.T. 1906. Notes on the Arbutus at Killarney. Journal of the Royal Society of Antiquaries of Ireland 36 (4): 433-435.

Mesléard, S. \& Lepart, J. 1989. Continuous basal sprouting from a lignotuber: Arbutus unedo L. and Erica arborea L. as woody Mediterranean examples. Oceologia 80: 127-131.

Mighall, T.M. \& Chambers, F.M. 1993. The environmental impact of prehistoric mining at Capa Hill, Cwmystwyth, Wales. The Holocene 3: 260-264.

Mighall, T.M., Chambers, F.M., Lanting, J.N. \& O'Brien, W.F. 2000. Prehistoric copper mining and its importance on vegetation: palaeoecological evidence from Mount Gabriel Co. Cork, south-west Ireland. In: Nicholson, R.A. \& O'Connor, T.P., eds. People as an Agent of Environmental Change: 19-29. Oxford: Oxbow Books.

Mitchell, F.J.G. 1988. Vegetational history of the Killarney oakwoods, SW Ireland: evidence from fine spatial resolution pollen analysis. Journal of Ecology 76 (2): 415-436.

Mitchell, F.J.G. 1990. The impact of grazing and human disturbance on the dynamics of woodland in SW Ireland. Journal of Vegetation Science 1: 245-254.

Mitchell, F.J.G. 1993. The biogeographical implications of the distribution and history of the strawberry tree, Arbutus unedo in Ireland. In: Costello, M.J. \& Kelly, K.S., eds. Biogeography of Ireland: past, present, and future: 35-44. Dublin: Irish Biogeographical Society.

Mitchell, F.J.G. 2006. Where did Ireland's trees come from? Biology \& Environment. Proceedings of the Royal Irish Academy, 106B (3): 251-9.

Mitchell, F.J.G. \& Cooney, T. 2004. Vegetation history of the Killarney valley. In: O'Brien, W., ed. Ross Island. Mining, metal and society in early Ireland. Bronze Age Studies 6: 481-493. Galway: National University of Ireland Galway.

Mitchell, G.F. \& Ryan, M. 1998. Reading the Irish Landscape. Dublin: Town House. 
Mitchell, G.F. \& Watts, W.A. 1970. The history of the Ericaceae in Ireland during the Quaternary Epoch. In: Walker, D. \& West, R.G., eds. Studies in Vegetational History of the British Isles: 13-21. Cambridge: Cambridge University Press.

Molyneux, T. 1697. A Discourse concerning the large Horns frequently found under ground in Ireland: concluding from them that the great American Deer, called a Moose, was formerly common in that island: with Remarks on some other things natural to that country. Philosophical Transactions, 19 (227): 489-512.

Moore, D. \& More, A.G. 1898. Contributions towards a Cybele Hibernica, being outlines of the geographical distribution of plants in Ireland. $2^{\text {nd }}$ ed. Dublin: Edward Ponsonby.

Nelson E.C. \& Walsh, W. 1993. Trees of Ireland. Dublin: The Lilliput Press.

Ní Shéaghdha, N., ed. 1967. Tóruigheacht Dhiarmada agus Ghráinne. The Pursuit of Diarmaid and Gráinne. Dublin: Irish Texts Society.

O'Brien, W. 2004. Ross Island: Mining, Metal and Society in Early Ireland, Bronze Age Studies, 6. Galway: National University of Ireland Galway.

O'Brien, W. 2012. Iverni: A Prehistory of Cork. Cork: The Collins Press.

O'Brien, W. 2015. Prehistoric Copper Mining in Europe: 5500-500 BC. Oxford: Oxford University Press.

O'Donovan, J. 1860. Pre-Christian Notices of Ireland. Ulster Journal of Archaeology 8: $239-251$.

O'Malley, J. 2001. Arbutus unedo. L. (Strawberry tree). Irish Botanical News 11: 467.

Overland, A., \& O'Connell, M. 2008. Fine-spatial paleoecological investigations towards reconstructing late Holocene environmental change, landscape evolution, and farming activity in Barrees, Beara Peninsula, Southwestern Ireland. Journal of the North Atlantic 1 (25): 37-73.

Parkinson, J. 1640. Theatrum Botanicum: The Theater of Plants. London: Thomas Cotes.

Power, T. 1845. The Botanist's Guide for the County of Cork. London, Cork: The Cuvierian Society of Cork.

Praeg, D., McCarron, S.G., Dove, D., Ó Cofaigh, C., Scott, G.A., Monteys, X., Facchin, L., Romeo, R. \& Coxon, P. 2015. Ice sheet extension to the Celtic Sea shelf edge at the Last Glacial Maximum. Quaternary Science Reviews 111: 107112. Available at: $<10.1016 / j$.quascirev.2014.12.010 $>$

Praeger, R. Ll. 1932a. Some noteworthy plants found in or reported from Ireland. Proceedings of the Royal Irish Academy, 41B (4): 95-124.

Praeger, R. Ll. 1932b. Recent views bearing on the problem of the Irish flora and fauna. Proceedings of the Royal Irish Academy, 41B (4): 125-145.

Praeger, R. LI. 1934. The Botanist in Ireland. Dublin: Hodges Figgis \& Co.

Preston, C.D., Pearman, D.A. \&d Dines, T.D. 2002. New Atlas of the Flora of the British \& Irish Flora. Oxford: Oxford University Press.

Proctor, M.C.F. 2002. Arbutus unedo Strawberry tree. In: Preston, C.D., Pearman, D.A. \& Dines, T.D. 2002. New Atlas of the Flora of the British \& Irish Flora. Oxford: Oxford University Press.

Queiroz, P. F. 2009. Sementes do silo do Bronze Final do Trigaches (Beja). Terra Scenica -Território Antigo relatórios. Report No 9. Lisbon. Available at: <https://bit.ly/2RdtiQi> 
Queiroz, P. F. 2010. Duas amostras de material vegetal carbonizado do povoado Calcolítico de Vila Nova de São Pedro, Azambuja. Terra Scenica -Território Antigo relatórios. Report No 21. Lisbon.

Quinn, B. 1984. Atlantean. Film documentary in 3 parts first shown by RTÉ television, Ireland. Digital version: < http://www.irishfilmfesta.org/en/2014-22/atlantean/>

Quinn, B. 2018. The Atlantean Irish. Updated edition with introduction by Barry Cunliffe. Dublin: The Lilliput Press.

Radcliff, T. 1814. Report of the Agriculture and Livestock of the County of Kerry. Dublin: Farming Society of Ireland.

Ray, J. 1696. De Variis Plantarum Methodis Dissertatio Brevis. London: Smith \& Walford.

Reich, I., Gormally, M., Allcock, A.L., Mc Donnell, R., Castillejo, J., Iglesias, J., Quinteiro, J. \& Smith, C.J. 2015. Genetic study reveals close link between Irish and Northern Spanish specimens of the protected Lusitanian slug Geomalacus maculosus. Biological Journal of the Linnean Society 116 (1): 156-68.

Santiso, X., Lopez, L, Retuerto, R.1., \& Barreiro, R, 2016. Phylogeography of a widespread species: pre-glacial vicariance, refugia, occasional blocking straits and long-distance migrations. AoB Plants 8: Available at : <plw003. doi: 10.1093/aobpla/plw003>

Scannell, M.J.P. \& O'Donnell, D. 1994. Report of Caha Mountains, West Cork (v.c. H3), 1st - 2nd August. Field Meeting reports for 1993. BSBI News 66: 54-55.

Scully, R. 1916. Flora of County Kerry, including the flowering plants, ferns, Characeae, \&c. Dublin: Hodges Figgis.

Sealy, J.R. 1949. Arbutus unedo. Journal of Ecology 37 (2): 365-388.

Sealy, J.R. \& Webb, D. A. 1950. Arbutus unedo L. Biological Flora of the British Isles. Journal of Ecology 38 (1): 223-236.

Sheehy Skeffington, M. 2018. An alien immigrant? The story of Mackay's Heath, Erica mackayana, in Ireland. Moorea 17: 61-70.

Sheehy Skeffington, M. \& Van Doorslaer, L. 2015. Distribution and habitats of Erica mackayana and Erica $\times$ stuartii: New insights and ideas regarding their origins in Ireland. New Journal of Botany 6 (1): 164-177.

Smith, C.M.D. 1756. The Antient and Present State of the County of Kerry. Dublin: Ewing, Faulkner, Wilson \& Exshaw.

Stoakley. T.E. 1986. The Knot in the Ring. $2^{\text {nd }}$ ed. Sneem: Sneem Tourist Association.

Tansley, A.G. 1949. The British Isles and their Vegetation. Vol I. Cambridge: Cambridge University Press.

Threlkeld, C. 1726. Synopsis stirpium Hibernicarum. Dublin: F. Davys, R. Norris and J. Worrall. [reissued in 1727]

Timberlake, S. 2014. 'Bronze Age Copper Mines in Wales, and a Brief Comparison with the Evidence from Ireland' Journal of the Mining Heritage Trust of Ireland 14: 103-123.

Timoney, M.B. 2002. Title. In: Timoney, M.A. A Celebration of Sligo: first essays for Sligo Field Club. Sligo: Sligo Field Club.

Tison, J-M. \& de Foucault, B. coords. 2014. Flora Gallica. Flore de France. Mèze, France: Biotope. 
Torres, J.A., Valle, F., Pinto, C., García-Fuentes, A., Salazar, C.\& Cano, E. 2002. Arbutus unedo L. communities in southern Iberian Peninsula mountains. Plant Ecology 160: 207-223.

Van Rijn P. 2004. The analysis of charcoal from Ross Island. In: O'Brien, W., ed. Ross Island. Mining, metal and society in early Ireland. Bronze Age Studies 6: 386-400. Galway: National University of Ireland Galway.

Veuillen, L. 2016. Reconnaître les particularités des forêts méditerranéennes françaises. Rapport de stage de fin de deuxième année. Nancy, France: AgroParisTech.

Vokes, E. 1966. Late-glacial and Post-glacial Vegetation of Killarney. MSc thesis. Dublin: University of Dublin.

Wakefield, E. 1812. An Account of Ireland, Statistical and Political. London: Longman, Hurst, Rees, Orme \& Brown.

Watts, W.A. 1984. Contemporary accounts of the Killarney woods 1580-1870. Irish Geography 17 (1) 1-13.

Webb, D.A. 1948. Some observations on the Arbutus in Ireland, The Irish Naturalists' Journal 9 (8): 198-203.

Webb, D.A. 1972. Arbutus L. In: Tutin, T.G., Heywood, V.H., Burges, N.A., Moore, D.M., Valentine, D.H., Walters, S.M. \& Webb D.A., eds. Flora Europaea, 3: 11. Cambridge: Cambridge University Press.

Webb, D.A. 1983. The flora of Ireland in its European context. Journal of Life Sciences, Royal Dublin Society 4 (2): 143-160.

Westropp T.J. 1908. The Forests of the Counties of the Lower Shannon Valley Proceedings of the Royal Irish Academy, 27: 270-300.

Wynne, J. 1860. On the effects of severe frost on plants in the neighbourhood of Sligo. Proceedings of the Natural History Society of Dublin (for the sessions 1849-1855) 1: 39-40.

Wyse Jackson, M., FitzPatrick, Ú., Cole, E., Jebb, M., McFerran, D., Sheehy Skeffington, M. \& Wright, M. 2016. Ireland Red List No. 10: Vascular Plants. Dublin: National Parks and Wildlife Service, Department of Arts, Heritage, Regional, Rural and Gaeltacht Affairs.

Wyse Jackson, P. 2014. Ireland's Generous Nature. The Past and Present Uses of Wild Plants in Ireland. St Louis, Missouri: Missouri Botanical Garden.

Copyright retained by author(s). Published by BSBI under the terms of the Creative Commons Attribution 4.0 International Public License.

ISSN: $2632-4970$

https://doi.org/10.33928/bib.2021.03.385 


\section{Appendix 1: Irish place names proposed in publications as indicating the presence of Arbutus unedo, along with any alternative derivations proposed by Irish experts.}

\begin{tabular}{|c|c|c|c|c|c|c|c|}
\hline Name & Locality & Source & $\begin{array}{l}\text { Proposed } \\
\text { derivation }\end{array}$ & $\begin{array}{l}\text { Alternative } \\
\text { derivation }\end{array}$ & Grid Ref & $\begin{array}{l}\text { Oldest written } \\
\text { record } \\
\text { or map }\end{array}$ & $\begin{array}{l}\text { Nearest } \\
\text { trees } \\
\text { today }\end{array}$ \\
\hline Ardcanny & $\begin{array}{l}\text { Ardcanny, } \\
\text { Adare, } \\
\text { Co. } \\
\text { Limerick }\end{array}$ & Logainm.ie* & $\begin{array}{l}\text { Ard caithne hill } \\
\text { of arbutus } \\
\text { (pre 9C Irish) }\end{array}$ & $\begin{array}{l}\text { Aird caithne: } \\
\text { headland of the } \\
\text { arbutus (P O } \\
\text { Cearbhall pers. } \\
\text { comm.) }\end{array}$ & R444566 & $\begin{array}{l}\text { (c. 1200) Black } \\
\text { Book of Limerick, } \\
\text { (1306) 'Papal } \\
\text { Taxation', } \\
\text { Ardcathny } \\
\end{array}$ & $95 \mathrm{~km}$ \\
\hline Ard na Caithne & $\begin{array}{l}\text { Smerwick, } \\
\text { Dingle, } \\
\text { Co. Kerry }\end{array}$ & $\begin{array}{l}\text { Kelly, F. } \\
\text { (1999) }\end{array}$ & $\begin{array}{l}\text { Ard na caithne } \\
\text { height of the } \\
\text { arbutus }\end{array}$ & $\begin{array}{l}\text { height of the } \\
\text { arbutus } \\
\text { (Logainm.ie) }\end{array}$ & Q357079 & $\begin{array}{l}\text { (1584) Desmond } \\
\text { Survey }\end{array}$ & $65 \mathrm{~km}$ \\
\hline Cahnicaun & $\begin{array}{l}\text { Killarney, } \\
\text { Co. Kerry }\end{array}$ & $\begin{array}{l}\text { Kelly F. } \\
\text { (1996) }\end{array}$ & $\begin{array}{l}\text { Caithneachán } \\
\text { little arbutusy } \\
\text { place }\end{array}$ & & R928832 & $\begin{array}{l}\text { (1829-42) 6" 1st } \\
\text { series O.S. maps }\end{array}$ & $<1 \mathrm{~km}$ \\
\hline Canagullen & $\begin{array}{l}\text { Glanmore } \\
\text { Lake, } \\
\text { Co. Kerry. }\end{array}$ & $\begin{array}{l}\text { Hall, M. } \\
\text { (2011) }\end{array}$ & $\begin{array}{l}\text { Caithne gualann } \\
\text { mountain } \\
\text { shoulder of the } \\
\text { arbutus }\end{array}$ & $\begin{array}{l}\text { Ceann na gCuileann: } \\
\text { head(land) } \\
\text { of the holly } \\
\text { (Logainm.ie) }\end{array}$ & V765543 & $\begin{array}{l}\text { (1829-42) 6" 1st } \\
\text { series maps }\end{array}$ & $<1 \mathrm{~km}$ \\
\hline Cappoquin & $\begin{array}{l}\text { Cappoquin } \\
\text { Co. } \\
\text { Waterford }\end{array}$ & $\begin{array}{l}\text { Joyce, P.W. } \\
\text { (1912) }\end{array}$ & $\begin{array}{l}\text { Quin = Cuinche: } \\
\text { land of the } \\
\text { arbutus }\end{array}$ & $\begin{array}{l}\text { Kelly, F. (1999) } \\
\text { dismisses proposed } \\
\text { etymology of } \\
\text { cuinche as 'not } \\
\text { possible' }\end{array}$ & X104994 & $\begin{array}{l}(1829-42) 6 " 1 s t \\
\text { series maps }\end{array}$ & $125 \mathrm{~km}$ \\
\hline $\begin{array}{l}\text { Coomerkane } \\
\text { Lake }\end{array}$ & $\begin{array}{l}\text { Hungry } \\
\text { Hill, } \\
\text { Adrigole, } \\
\text { Co. Cork }\end{array}$ & $\begin{array}{l}\text { Hall, M. } \\
\text { (2011) }\end{array}$ & $\begin{array}{l}\text { Cumar caithne } \\
\text { valley of the } \\
\text { arbutus }\end{array}$ & $\begin{array}{l}\text { Com Earcán: hollow } \\
\text { of Earcán } \\
\text { (Logainm.ie) }\end{array}$ & V895563 & $\begin{array}{l}\text { (1829-42) 6" 1st } \\
\text { series maps }\end{array}$ & $2 \mathrm{~km}$ \\
\hline $\begin{array}{l}\text { Coomerkane } \\
\text { Stream }\end{array}$ & $\begin{array}{l}\text { Glengarriff } \\
\text { Co. Cork }\end{array}$ & $\begin{array}{l}\text { Hall, M. } \\
\text { (2011) }\end{array}$ & $\begin{array}{l}\text { Cumar caithne } \\
\text { valley of the } \\
\text { arbutus }\end{array}$ & $\begin{array}{l}\text { Com Earcán: hollow } \\
\text { of Earcán } \\
\text { (Logainm.ie) }\end{array}$ & V768493 & $\begin{array}{l}(1829-42) 6 " 1 s t \\
\text { series maps }\end{array}$ & $<1 \mathrm{~km}$ \\
\hline $\begin{array}{l}\text { Derrynacaheny } \\
\text { Wood }\end{array}$ & $\begin{array}{l}\text { Derrymore } \\
\text { Crusheen, } \\
\text { Co. Clare }\end{array}$ & $\begin{array}{l}\text { Westropp, } \\
\text { T.J. } \\
(1909)\end{array}$ & $\begin{array}{l}\text { Doire na } \\
\text { caithne: } \\
\text { oak-wood of the } \\
\text { arbutus }\end{array}$ & & R423848 & $\begin{array}{l}(1829-42) 6 " 1 \text { st } \\
\text { series maps }\end{array}$ & $130 \mathrm{~km}$ \\
\hline $\begin{array}{l}\text { Isknagahiny } \\
\text { Lough }\end{array}$ & $\begin{array}{l}\text { Cloghvoola } \\
\text { Waterville, } \\
\text { Co. Kerry }\end{array}$ & Logainm.ie & $\begin{array}{l}\text { Eisc na } \\
\text { gCaithne: } \\
\text { hollow with cliffs } \\
\text { of the arbutus } \\
\end{array}$ & & V575655 & $\begin{array}{l}(1829-42) 6 " 1 s t \\
\text { series maps }\end{array}$ & $2 \mathrm{~km}$ \\
\hline $\begin{array}{l}\text { Log ba na } \\
\text { gCaithne }\end{array}$ & $\begin{array}{l}\text { Tooreens, } \\
\text { Waterville, } \\
\text { Co Kerry }\end{array}$ & Logainm.ie & $\begin{array}{l}\text { Log bán na } \\
\text { gcaithne? white } \\
\text { hollow of the } \\
\text { arbutus }\end{array}$ & & V575665 & $\begin{array}{l}\text { (1968) } \\
\text { Logainm.ie; }\end{array}$ & $4 \mathrm{~km}$ \\
\hline $\begin{array}{l}\text { Owenacahina } \\
\text { Stream }\end{array}$ & $\begin{array}{l}\text { Glengarriff } \\
\text { Co. Cork }\end{array}$ & $\begin{array}{l}\text { Joyce, P.W. } \\
\text { (1912) }\end{array}$ & $\begin{array}{l}\text { Abhainn na } \\
\text { Caithne } \\
\text { stream of the } \\
\text { arbutus }\end{array}$ & & V885573 & $\begin{array}{l}\text { (1829-42) 6" 1st } \\
\text { series maps }\end{array}$ & $<1 \mathrm{~km}$ \\
\hline Quinn & $\begin{array}{l}\text { Quinn, } \\
\text { Co. Clare }\end{array}$ & $\begin{array}{l}\text { Joyce, P.W. } \\
\text { (1912) }\end{array}$ & $\begin{array}{l}\text { Cuinche } \\
\text { land of the } \\
\text { arbutus }\end{array}$ & $\begin{array}{l}\text { Kelly, F. (1999) } \\
\text { dismisses proposed } \\
\text { etymology of } \\
\text { cuinche as 'not } \\
\text { possible' }\end{array}$ & R418745 & $\begin{array}{l}(1829-42) 6 " 1 s t \\
\text { series maps }\end{array}$ & $140 \mathrm{~km}$ \\
\hline
\end{tabular}

* www.logainm.ie : Placenames Database of Ireland 